\title{
The genetics of malignant melanoma
}

Jesus Lomas ${ }^{1}$, Pilar Martin-Duque ${ }^{2}$, Mar Pons ${ }^{1}$, Miguel Quintanilla ${ }^{1}$

${ }^{I}$ Instituto de Investigaciones Biomedicas Alberto Sols, Consejo Superior de Investigaciones Cientificas-Universidad Autonoma de Madrid, and ${ }^{2}$ Facultad de Ciencias Biosanitaria, Universidad Francisco de Vitoria (PM-D), Madrid, Spain

\section{TABLE OF CONTENTS}

1. Abstract

2. Introduction

3. Susceptibility genes

3.1. The CDKN2A locus and familial melanoma

3.2. $M S H / M C 1 R$ and the regulation of pigmentation

4. Genetic alterations found in sporadic melanoma

4.1. Receptor tyrosine kinases

4.2. RAF, RAS, and the mitogen-activated protein kinase (MAPK) pathway

4.3. PTEN and the phosphatidylinositol 3'-kinase (PI3K) pathway

4.4. Microphthalmia-associated transcriptional factor

4.5. The Wnt/beta-catenin signaling pathway

5. Genetically engineered animal models of melanoma

6. Genomic and gene-expression profiling studies

6.1. Gene expression profiles

6.2. Comparative genomic hybridization

7. Melanoma stem cells

8. Conclusions and perspectives

9. Acknowledgements

10. References

\section{ABSTRACT}

Melanoma probably is the most aggressive cancer in humans and remains one of the leading causes of cancer death in developed countries. This review summarizes the most important alterations in protooncogenes and tumor suppressor genes that contribute to the pathogenesis of malignant melanoma, with a special emphasis on the involved signaling pathways. Our knowledge of the molecular biology of melanoma has been benefited from recent advances on high-throughput technologies analyzing wide genomic and gene expression profiles that have uncovered unknown candidate genes. To test the interactions between distinct pathways and of those with the environment a wealth of genetically modified animal models has been generated over the past years. Other studies have focused on the isolation of melanoma stem cells and on the characterization of signaling pathways that contribute to their survival and maintenance. A consequence of all these studies is the emergence of potential new strategies that could improve the still unadequate arsenal of therapeutic tools to fight against this fatal disease.

\section{INTRODUCTION}

The incidence of melanoma is rising by $3-8 \%$ per year in the Caucasian population (1). This fact together with the lack of remarkable therapeutic improvements represents a relevant health problem throughout the world. Melanomas derive from melanocytes, the pigment producing cells that mainly reside in the skin, although they can also arise from melanocytes residing in non-cutaneous tissues, such as the pigmented layer of the eye that includes the iris, ciliary body and chroids (uveal melanoma) or internal mucosal membranes (mucosal melanoma). Exposure to the sun is widely accepted as a major causative factor for melanoma development. Both UV components of sunlight: UVA (320-400 nm) and the UVB (290-320 nm) appear to be involved in the genesis of melanoma (2). Most of UVB light is absorbed by the ozone, but $5-10 \%$ of it reaches the earth surface. The exposure to UVB radiation leads the formation of pyrimidine pyridine photoproducts and cyclobutane pyrimidine dimer, whose incorrect repair leads to DNA mutations ( $\mathrm{C}$ to $\mathrm{T}$ and $\mathrm{CC}$ to $\mathrm{TT}$ transitions). On the other hand, UVA genotoxicity is principally due to 


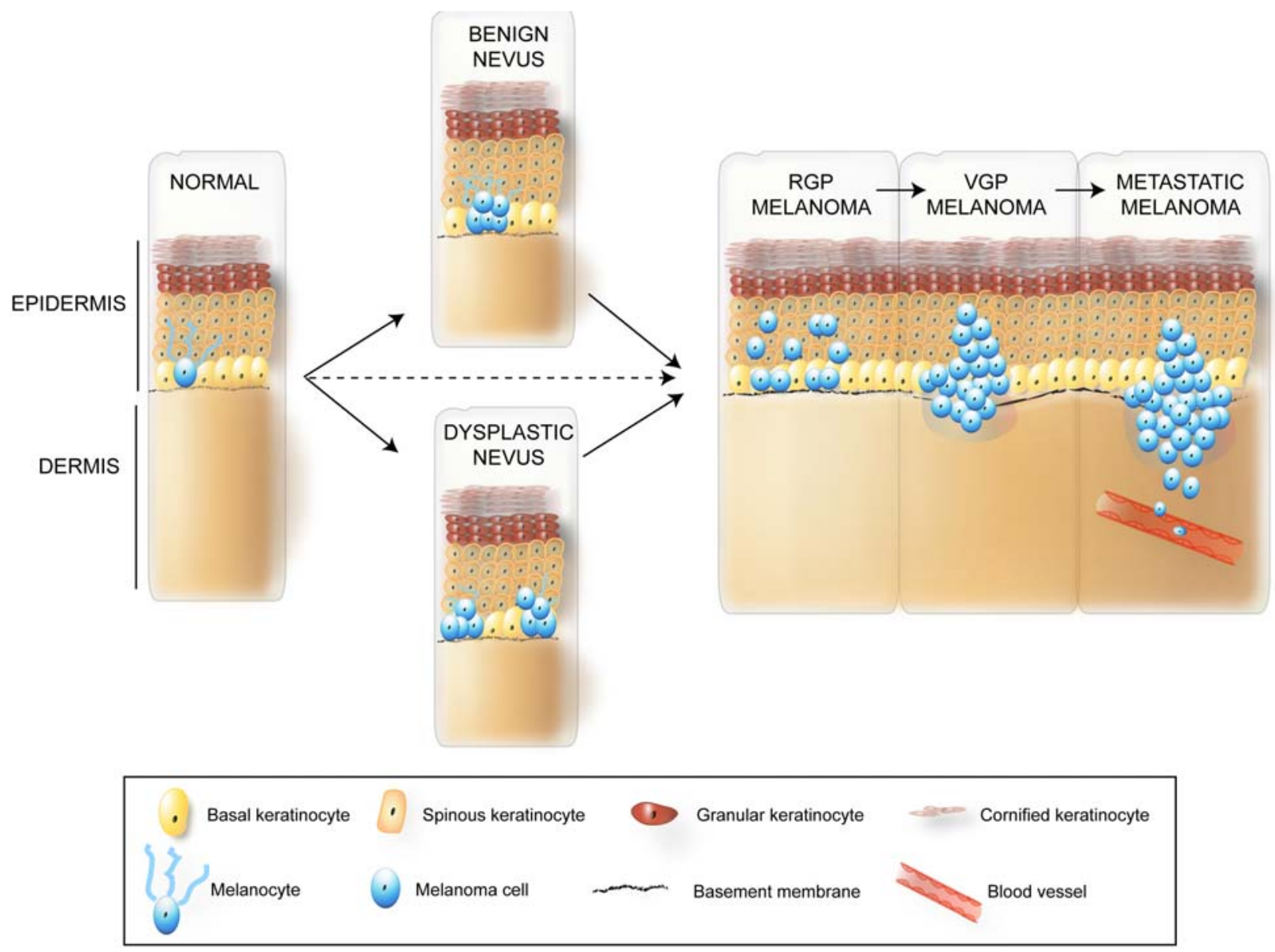

Figure 1. Development of malignant melanoma. Metastatic melanoma is thought to arise by a multi-step process from precursor lesions such as benign nevus or dysplastic nevus. RGP, radial growth phase; VGP, vertical growth phase.

indirect mechanisms mediated by reactive oxygen radicals (3). Melanin is the pigment synthesized within melanosomes in melanocytes; in the skin it acts as a filter by absorbing solar radiation.

There are some paradoxes, however, regarding to the role of UV in the genesis of melanoma. In contrast to other common skin tumours, such as squamous cell carcinoma, melanoma results from intense rather than cumulative sun exposure, particularly during childhood (2, 4). Thus, melanoma arises most commonly on the trunk, arms and legs than on areas that are chronically exposed to the sun, such as the face. In addition, there is no obvious linkage between UV irradiation and tumours arising in the palms of the hands and the soles of the feet (acral melanoma) or in mucosal membranes. Cutaneous melanoma has been classified into several histopathological stages: superficial spreading is the most common form of melanoma in Caucasians, lentigo malignant melanoma generally occurs on chronically exposed skin of the elderly, acral lentiginous melanoma is the predominant form of this disease in individual with darker skin, and nodular melanoma is characterized by the vertical growth of transformed melanocytes $(5,6)$. However, this classification is controversial since a substantial number of melanomas do not fit these types and, therefore, it has not been universally adopted in clinical practice (6-8). Five sequential steps (9) describe the histological changes that in most cases accompany the progression from normal melanocytes to metastatic melanoma: common acquired and congenital nevi without dysplasia (benign nevi), dysplastic nevi, radial-growth phase (RGP) melanoma, vertical-growth phase (VGP) melanoma and metastatic melanoma (Figure 1). Alternatively, RGP or VGP melanomas may arise direct from a skin without a previous benign or borderline melanocitic lesion. In all cases, it is believed that the crucial step in the evolution of malignant melanoma is the transition from RGP to VGP melanoma since, unlike RGP melanomas, VGP melanomas can undergo anchorage-independent growth and have acquired metastatic competence (10).

\section{SUSCEPTIBILITY GENES}

The most significant risk factor for melanoma occurs in individuals with a familial melanoma history. In families with multiple cases of melanoma, the pattern of susceptibility is consistent with the inheritance of autosomal dominant genes with incomplete penetrance, and the number of tumors developed might be determined by 
the interaction of several factors: the presence of a hereditary susceptibility, sun exposure and other genes that mitigate the response of the skin to the sun, such as the melanocortin-1 receptor gene $(M C 1 R)(11)$. Two genes have been found to be associated with high-penetrance susceptibility: $C D K N 2 A$, the most prevalent in families with melanoma, and $C D K 4$. Nevertheless, it is well known how physical characteristics, such as fair-skin, red or blond hair, the inability to tan and a freckling phenotype, correlate with increased risk for melanoma development. Since certain MC1R polymorphic variants are associated with these characteristics and with a diminished ability of the epidermis to respond to UV damage, this pigment regulating gene is seen as a low-penetrance melanoma susceptibility gene (12-14). Co-inheritance of these $M C 1 R$ variants increases the penetrance in CDKN2A families (15, 16). A predisposition to skin cancer is also associated with the rare hereditary syndrome xeroderma pigmentosum (XP). Individuals with XP carry a nucleotide excision DNA repair defect associated with an acute photosensitivity. The most significant characteristic of XP patients is a predisposition to develop multiple skin cancers, mostly squamous cell carcinomas but also basal cell carcinomas and malignant melanomas (17).

\subsection{The $C D K N 2 A$ locus and familial melanoma}

Familial melanomas represent about $8-12 \%$ of all melanoma cases. The first melanoma susceptibility gene, $C D K N 2 A$, was identified at a locus at $9 \mathrm{p} 21$ by linkage analysis studies of families with high melanoma incidence $(18,19) . C D K N 2 A$ encodes two unrelated proteins: p16Ink4a and p14Arf (the homologous of p19 Arf in mice) by a combination of alternative splicing and reading frames (Figure 2A). Both $C D K N 2 A$ products are potent tumor suppressors involved in cell cycle regulation. p16Ink4a inhibits G1 cyclin-dependent kinases Cdk4/Cdk6-mediated phosphorylation of the retinoblastoma protein $(\mathrm{pRb})$, arresting cell cycle progression through G1-S (20), whereas p14Arf favours apoptosis and blocks oncogenic transformation by stabilizing p53 levels through inhibition of Mdm2-mediated p53 ubiquitination (21-24). Hence, the loss of p16Ink4a function promotes hyperphosphorylation and inactivation of $\mathrm{pRb}$, while loss of p14Arf inactivates p53, both leading to unrestricted cell cycle progression (Figure 2B).

Germline $C D K N 2 A$ mutations have been found up to $40 \%$ of families with 3 or more members affected by the disease and in $10 \%$ of families with 2 affected members. They are constituted by missense mutations of exons 1alpha, exon 2, the 5 ' untranslated region and introns (see ref. 25 for review). As p16INK4A shares exon 2 with p14ARF (see Figure 2A), many $C D K N 2 A$ mutations affect both proteins confounding the effective role of each gene in the melanoma genesis. Mutations affecting only $p 14 A R F$ have been described in some melanoma families (26-28); this findings supports the role of $p 14 A R F$ as a melanoma susceptibility gene independent of $p 16 I N K 4 A$. In addition, genetically mouse models have provided convincing evidence that both $p 14 A R F$ and pl6INK4A are tumor suppressor genes in melanoma development (see below).
The penetrance of $C D K N 2 A$ is incomplete and shows variations between continents, countries and populations $(11,29)$. Thus, not all individuals carrying germline $C D K N 2 A$ mutations will develop a melanoma. The presence of large numbers of pigmented lesions, including benign or clinically atypical nevi, known as familial atypical multiple mole-melanoma syndrome or atypical mole syndrome (FAMM or AMS, respectively) is associated with an increased risk to develop melanoma (30). However, FAMM cannot be used to predict genecarrier status in families with germline $C D K N 2 A$ mutations, and, although the presence of FAMM increases the probability of melanoma in families, melanoma occurs in individuals who do not have FAMM (11). Some families carrying $C D K N 2 A$ mutations also seem to be at increased risk of pancreatic cancer $(31,32)$. However, the precise relationship between pancreatic cancer and the $C D K N 2 A$ locus remains elusive. Some authors have proposed that the type of mutation in $C D N K 2 A$ affects risk of pancreatic cancer (33).

A second melanoma susceptibility gene, $C D K 4$, was found at chromosome 12q14 (34-36). Germline and sporadic mutations in $C D K 4$ abrogating binding of $\mathrm{Cdk} 4$ to p16Ink4a (see Figure 2B) have been found associated with melanoma pathogenesis. Conversely, a mutation affecting exon 1alpha of p16INK4A impairing binding of p16Ink4a protein to $\mathrm{Cdk} 4$, but not $\mathrm{Cdk} 6$, has been recently reported (37). These results suggest that Cdk4 and Cdk6 are not functionally redundant, and emphasize the importance of CDK4 for the development of melanoma. Thus, mutations in this gene have a similar impact to those in p16INK4a, and the phenotypic characteristics of families carrying germline $C D K 4$ mutations do not differ from those families affected in the $C D K N 2 A$ locus $(38,39)$. Consistent with the human data, mice expressing a mutant form of $C d k 4$ are predisposed to develop melanoma after carcinogen treatment (40). Moreover, evidence that links the entire p16Ink4a-Cdk4/Cdk6-pRb pathway to melanoma is the observation that hereditary retinoblastoma patients with germline inactivation of the retinoblastoma gene $(R B 1)$ are predisposed to melanoma $(41,42)$.

Not all families with multiple cases of melanoma have identifiable $C D K N 2 A$ or $C D K 4$ mutations, and, therefore, other high-penetrance susceptibility genes remain to be identified. For example, there is evidence for another as yet unidentified melanoma susceptibility gene at chromosome 1p22 $(43,44)$.

\subsection{Melanocortin receptor 1 and the regulation of pigmentation}

When the alpha-melanocyte-stimulating hormone (alpha-MSH) binds to its seven-transmembrane G-proteincoupled receptor MC1R, which is present in epidermal melanocytes, it triggers an intracellular signaling pathway that is considered the most important regulator of pigmentation (25). This pathway involves activation of adenylate cyclase and production of cyclic AMP (cAMP). Elevated cAMP levels leads to phosphorylation and activation of the cAMP responsive element binding (CREB) family of transcription factors (Figure 3A). A 


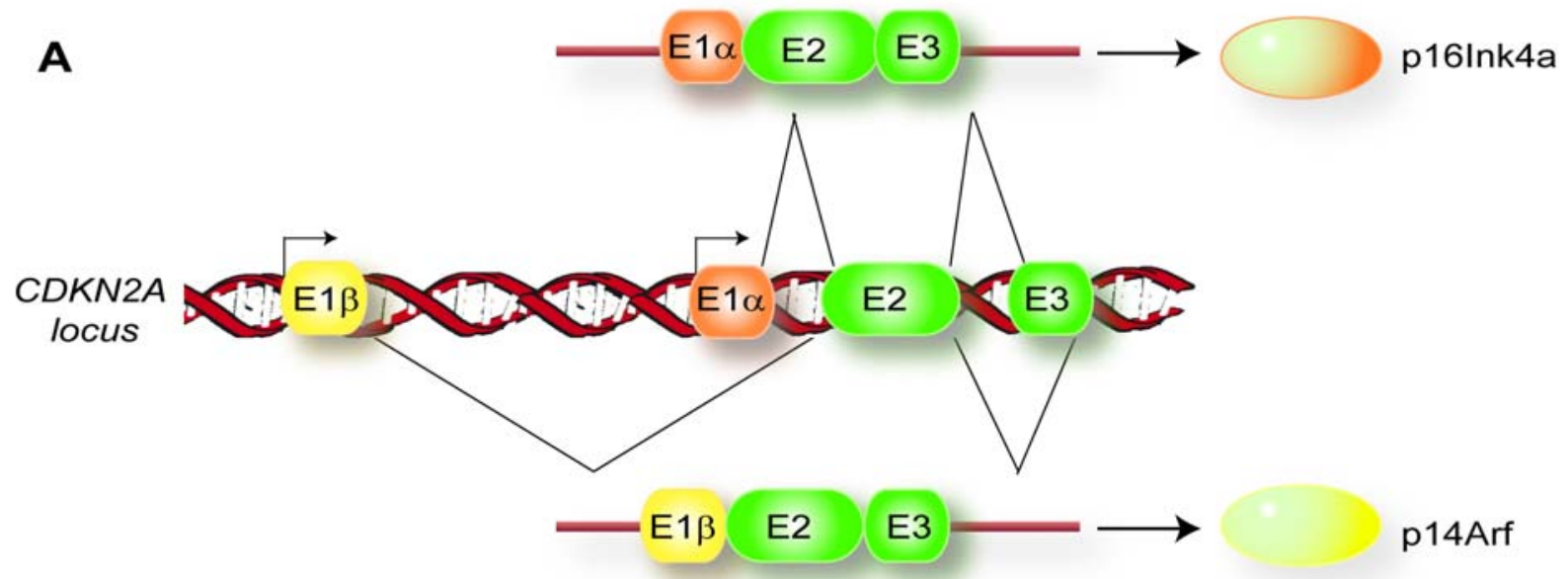

B
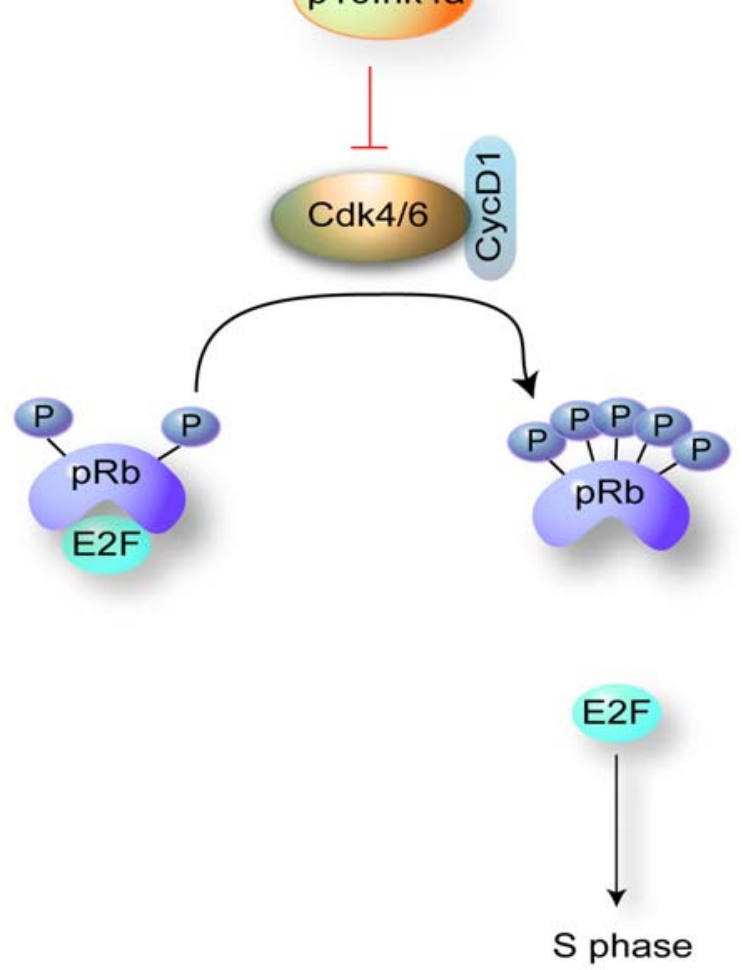

p14Arf

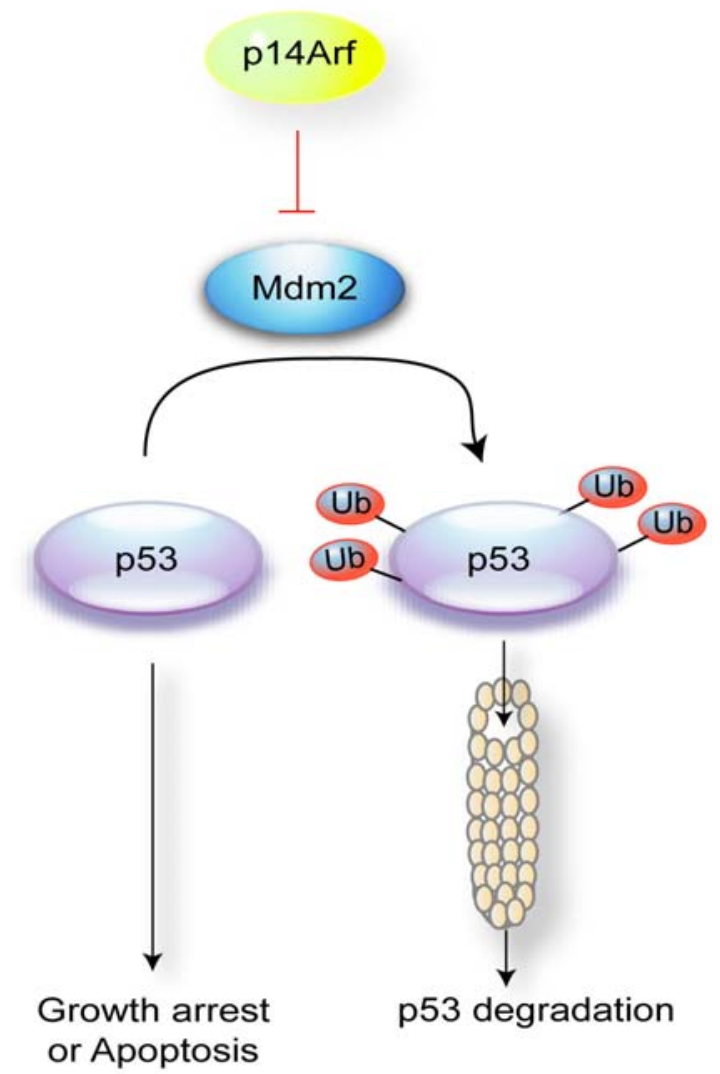

Figure 2. The CDNK2A locus. (A) Both p16Ink4a and p14Arf proteins are encoded by the CDNK2A gene. Each protein has a unique first exon (E1beta or E1alpha) that splices to a common second and third exon but in alternating reading frames. (B) p16Ink4a binds directly to cyclin-dependent kinases Cdk4 and Cdk6 blocking the assembly of catalytically active cyclinD-Cdk complexes. By phosphorylating members of the $\mathrm{pRb}$ family, these Cdk complexes enable the transcription of genes that are under the control of the E2F family of transcription factors. Elevated expression of p16Ink4a causes a G1-phase cell cycle arrest that is dependent on functional pRb. p14Arf stabilizes and enhances p53 level by inhibiting Mdm2-mediated p53 ubiquitination and degradation through the proteasome. p53 accumulation leads to either cell cycle arrest or apoptosis.

critical CREB target gene is that encoding the microphthalmia associated transcription factor (Mitf) (45, 46), a basic helix-loop-helix leucine zipper (b-HLH-Zip) factor that in turn regulates the transcription of genes encoding enzymes that are essential for melanin synthesis, such as tyrosinase, tyrosinase-related protein-1 (TRP-1) 


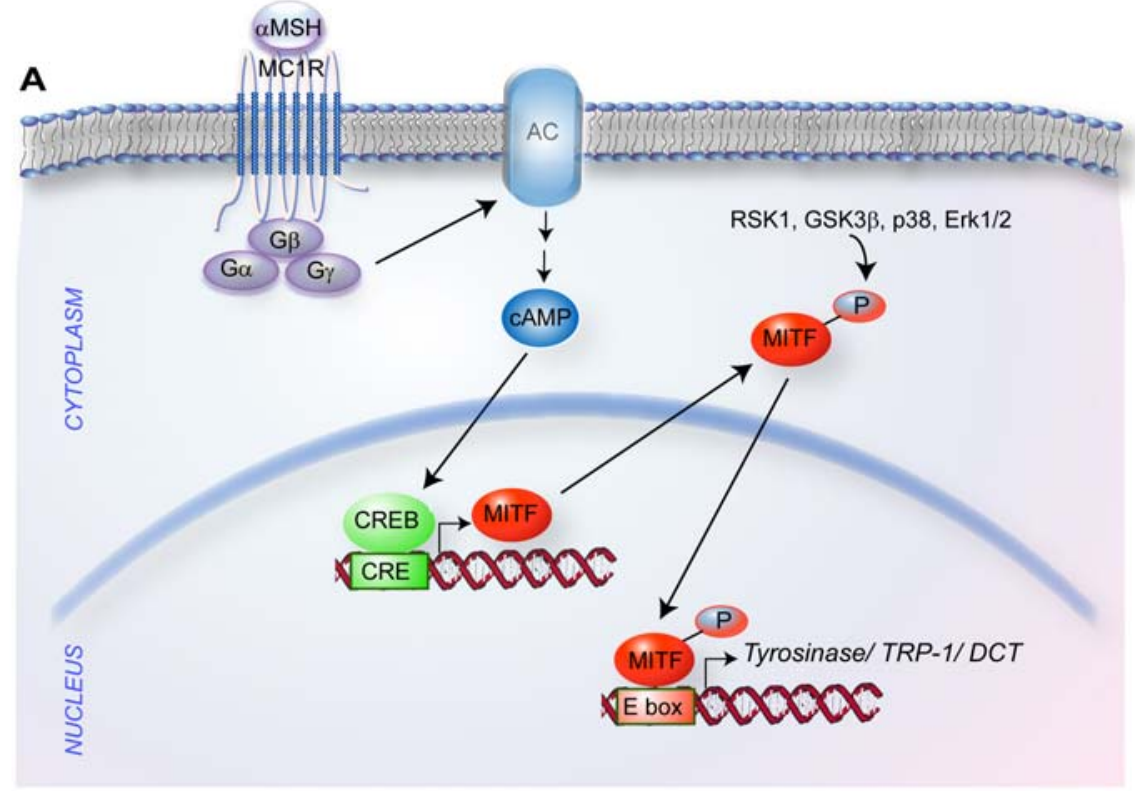

B

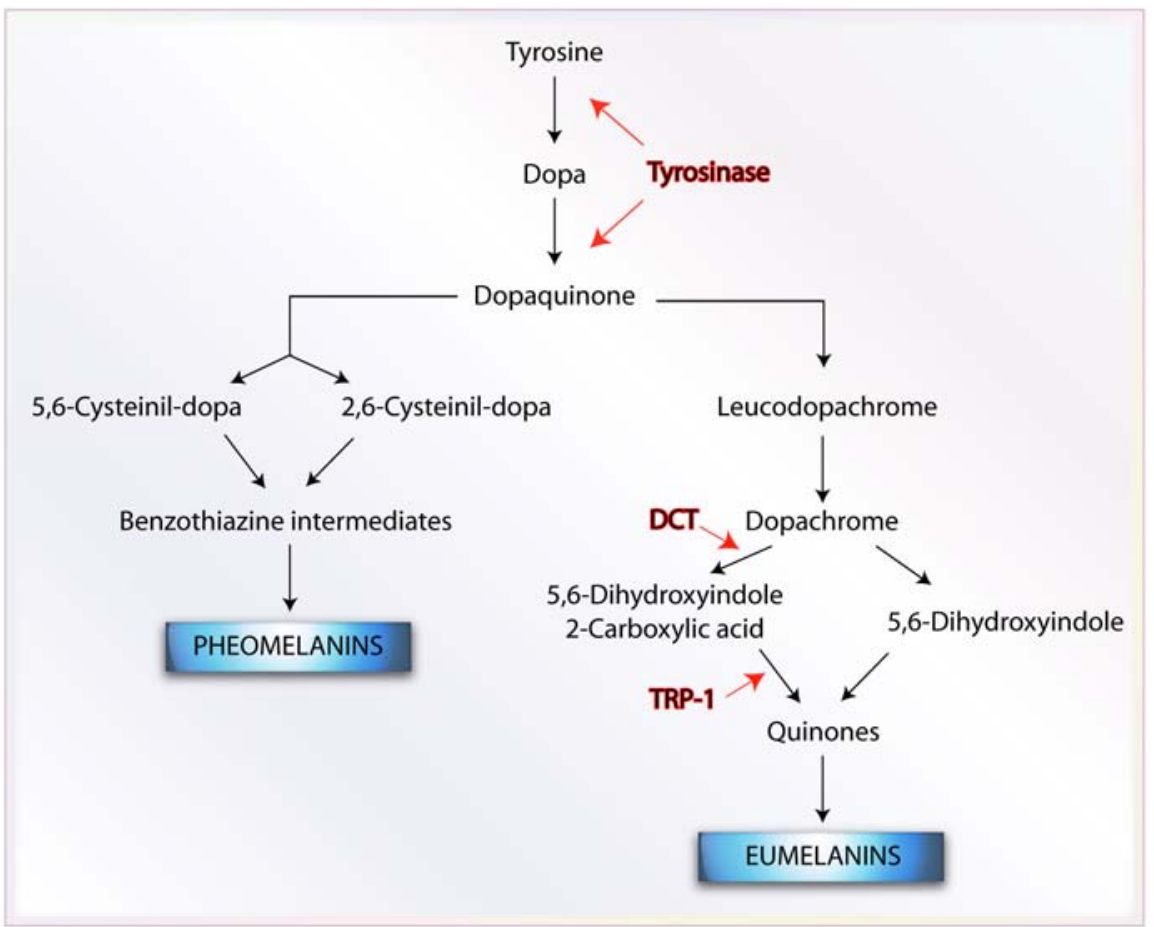

Figure 3. (A) The MC1R signaling pathway. Binding of alpha-MSH to MC1R activates adenylate cyclase (AC) through a heterotrimeric G-protein complex. AC catalyzes the production of cAMP which leads to the phosphorylation of members of the CREB family of transcription factors. Activated CREB recruits $\mathrm{CBP} / \mathrm{p} 300$ coactivators triggering transcriptional activation of multiple genes. MITF is a critical CREB target gene in melanocytes. Mitf can be phosphorylated by several kinases; i.e., extracellular-regulated kinase (Erk), ribosomal S6 kinase (RSK), GSK3beta, and p38MAPK. Activated Mitf regulates genes involved in pigmentation and differentiation. (B) Biochemical pathways leading to the synthesis of melanins. TRP-1, tyrosinaserelated protein 1; DCT, dopachrome tautomerase (also called TRP-2).

and dopachrome tautomerase (DCT) (Figure 3B). $M C 1 R$ is highly polymorphic in the human population. Some $M C 1 R$ variants are associated with the Red Hair Color (RHC) phenotype, characteristic of individuals with red hair, fair skin, resistance to tan and freckle tendency. These individuals synthesize increased amounts of the potentially dangerous pheomelanin (reddish-yellow pigment) instead of the protective, photoreactive black-brown pigment 
eumelanin (Figure 3B). In addition to its diminished UVlight protective capacity, pheomelanin produces cytotoxic and mutagenic metabolites and presumably contributes to increase melanoma risk $(12,13,25)$. In general, those $M C 1 R$ variants that produce weak or absent cAMP response to alpha-MSH signals are associated with the RHC phenotype (47) and, therefore, they can be classified as low-risk melanoma susceptibility genes.

Although the current evidence supports the idea that sun exposure is causal for melanoma, the nature of the exposure appears to be also an important factor. Melanoma occurs most frequently after intermittently sun exposure and in individuals with frequent sunburns. Indeed, some epidemiological studies suggest that chronic sun exposure may protect individuals against melanoma (48). However, this is controversial as other studies support the view that cumulative sun exposure is a risk factor for melanoma (reviewed in ref. 11). Some authors have proposed that the effect of sun exposure might be lower in families with high-penetrance susceptibility genes than in those with low-penetrance susceptibility genes (49).

\section{GENETIC ALTERATIONS FOUND IN SPORADIC MELANOMA}

Despite its important role in melanoma predisposition, single mutations in the $C D K N 2 A$ locus are rarely found in sporadic primary melanomas. However, deletions of $9 \mathrm{p}$, where $C D N K 2 A$ is located, occur in $50 \%$ of sporadic melanomas, as found in a genome-wide analysis of chromosomal alterations (see below). Furthermore, a recent study has reported biallelic $C D K N 2 A$ deletions in about $45 \%$ of melanoma metastases, emphasizing a role of this locus in melanoma progression (50). Some reports have found silencing of pI6INK4A due to promoter hypermethylation in $19 \%$ of primary cutaneous melanomas and in $33 \%$ of the corresponding metastases (51). A higher frequency for $p 16 I N K 4 A$ promoter hypermethylation (33\%) has been reported for uveal melanoma (52). In many cases, tumors are heterogeneous showing both methylated and unmethylated tumor cells $(52,53)$. In contrast to primary tumors, $C D K N 2 A$ mutations are found frequently in melanoma cell lines (reviewed in ref. 39), a fact likely reflecting a selective event imposed by cell culturing due to the critical role of p16Ink4a in senescence, as cells that lose p16Ink4a escape senescence and become immortalized.

As the gene encoding p53 (TP53) is the most frequent tumor suppressor inactivated in human cancer, it is surprising that the proportion of primary and metastatic melanomas containing mutations in TP53 is consistently low. Although UV light-related TP53 mutations are frequently observed in other skin tumors, such as basal and squamous cell carcinomas $(17,54)$, the above observation suggests that $\mathrm{UV}$-induced mutational inactivation of $\mathrm{p} 53$ is not involved in melanoma formation. As p14Arf and p53 are within the same pathway (see Figure 2B), the low frequency of p53 mutations in melanoma can be partially explained by the loss of p14Arf, via 9p21 deletion, which results in inactivation of the p53 pathway $(25,55)$. However, there is convincing evidence suggesting p53- independent functions for Arf in a variety of cellular processes, including DNA-damage and apoptosis (56). Thus, a recent report using a genetically engineered mouse model has provided experimental evidence demonstrating that p19Arf, and not p53, acts as a suppressor of melanoma formation by inducing senescence in melanocytes (57). Strikingly, melanomas from XP patients with defective nucleotide excision repair (NER) pathway show a high TP53 mutation frequency of $>50 \%$ (17). It should be of interest to know whether $C D K N 2 A$ gene alterations exist in $\mathrm{XP}$ melanomas, as there is no published report in this respect. Interestingly, abrogation of NER combined with $C d k n 2 a$ inactivation in a genetically engineered mouse model can drive melanomagenesis induced by a single, neonatal, UVB exposure (58). Besides $\mathrm{pRb}$ and Arf/p53, genetic and molecular studies have identified several important molecules and signaling pathways whose altered regulation appears to be crucial for the development of melanoma, as set out immediately below.

\subsection{Receptor tyrosine kinases}

c-Met is a receptor tyrosine kinase involved in the growth, invasion and metastasis of cancer cells. The natural ligand of c-Met is the hepatocyte growth factor/scatter factor (HGF/SF), a multifunctional cytokine that acts as a mitogen, motogen and morphogen for epithelial cells. In normal skin, c-Met is expressed in keratinocytes and melanocytes, whereas $\mathrm{HGF} / \mathrm{SF}$ is secreted mainly by mesenchymal cells within the dermis (59). Several studies support the view that an autocrine $\mathrm{HGF} / \mathrm{SF} / \mathrm{c}-\mathrm{Met}$ signaling loop is involved in the development of melanoma (60). Increased expression of cMet has been observed in metastatic melanoma $(61,62)$, and gain of the 7q33-qter locus (where $c-M E T$ is located) has been correlated with late stages of melanoma development $(63,64)$. In addition, a recent report describes the presence of $c-M E T$ activating mutations in some melanoma cell lines and tumor tissues (65). Melanoma cells, but not melanocytes, produce HGF/SF, which can induce sustained activation of its receptor (60). The cellcell adhesion protein E-cadherin mediates the association between keratinocytes and melanocytes within the basal layer of the epidermis, and these contacts inhibit melanocyte proliferation and suppress the expression of melanoma markers $(66,67)$. Besides to stimulate melanocyte proliferation and motility, $\mathrm{HGF} / \mathrm{SF}$ disrupts adhesion between melanocytes and keratinocytes by downregulating the expression of E-cadherin and desmoglein-1, which could favour deregulated cell proliferation and invasiveness (60). Interestingly, $c-M E T$ is a transcriptional target of Mitf, the melanocytic lineage transcription factor (68). As described below, the Mitf encoding gene $(M I T F)$ is amplified in malignant melanoma, which might account for c-Met overexpression in advanced melanoma. The causal relationship between c-Met signaling and malignant melanoma is supported by in vitro experiments and genetically engineered models (25).

Other reports have also related overexpression of the epidermal growth factor receptor (EGFR), linked to gains of chromosome 7 , to advanced melanoma $(66,69)$. $E G F R$ is often amplified in breast and lung carcinomas, and 
overexpression of this tyrosine kinase receptor in tumors is thought to result in deregulated kinase activity and malignant transformation (70). An important effector of oncogenic receptor tyrosine kinases is the phosphatydilinositol 3'-kinase (PI3K)-Akt pathway that controls cell survival and motility.

\subsection{Raf, Ras, and the mitogen-activated protein kinase} pathway

Raf proteins are serine/threonine kinases that are the primary mediators of Ras signaling. Ras links extracellular mitogenic stimuli to transcription of genes that regulate cell growth, differentiation, survival, senescence, cell shape and cell migration, via the mitogen-activated protein kinase (MAPK) pathway (71) (Figure 4A). In humans, there are three highly conserved $R A F$ genes, $A R A F, B R A F$ and $C R A F$, which appear to play distinct biological roles. In melanocytic lesions, the most frequent activating mutations found in protooncogenes are those leading to constitutive activation of the MAPK signaling cascade. Strikingly, mutations in $B R A F$ resulting in constitutive activation of this kinase have been found frequently $(27-70 \%)$ in melanoma (72-74). Most of these $B R A F$ mutations occur at a single site (T-A transversion) leading to the substitution of glutamic acid for valine (V600E) at the kinase domain, which confers constitutive activation of the MAPK pathway and constitutive nuclear factor-kappaB (NF-kappaB) signaling, although it is currently unknown how NF-kappaB is activated by oncogenic $B R A F$ (75). NF-kappaB regulates the expression of a number of chemokines, such as CXCL8, that are thought to enhance melanoma progression by autocrine and paracrine loops. Thus, overexpression of CXCL8 in melanoma is associated with the transition from RGP to VGP melanoma and with enhanced angiogenesis (reviewed in ref. 76). $B R A F$ mutations are common in benign and dysplastic nevi $(72,77)$, pointing to a potential initiating role of $B R A F$ in melanocyte transformation. Expression of mutant $\mathrm{BRaf}^{\mathrm{V} 600 \mathrm{E}}$ protein in cultured human melanocytes induces p16Ink4a-dependent cell cycle arrest and non-p16Ink4a-dependent cell senescence (78). These observations indicate the presence of a tumor suppressor within this latter unknown pathway leading to senescence, whose inactivation ought to cooperate with $B R A F$ mutations for melanoma progression (25). The notion that $B R A F$ mutation is not sufficient for a full melanocyte neoplastic transformation is also supported by a genetically engineered fish model (see below). The $B R A F^{V 600 E}$ point mutation is not classically associated with UV damage, giving rise to the question of the role of sun exposure on $B R A F$ mutations occurring in melanoma (79). Mutations in BRAF (also mutations in $N-R A S$, see below) are rare in melanomas arising in sites exposed to chronic UV damage and in acral and mucosal melanomas, but are frequent (about 81\%) in melanomas occurring as a consequence of episodes of acute, high intensity UV exposure, such as the back or trunk (80). BRAF mutations are also absent in UV-induced non-melanoma skin cancers, such as basal and squamous cell carcinomas (81). It has been proposed that $B R A F$ mutations in melanoma are not induced directly by UV irradiation, but are a secondary consequence of UV exposure due to highly toxic oxidazing agents, inflammation and erythema (75).
Other reports have documented $R A S$ gene mutations in melanocytic tumors. The most frequently mutated member of the family is $N-R A S$, while mutations in $H-R A S$ and $K-R A S$ have only been found occasionally. Activating point mutations in $N-R A S$ have been reported in as many as $56 \%$ of congenital nevi, $33 \%$ of primary melanomas and $26 \%$ of metastatic melanoma samples, but are rarely found in dysplastic nevi (82-84). Since $B R A F$ mutations, but not $N-R A S$ mutations, are frequent in dysplastic nevi, this fact indicates the possible existence of two distinct evolutionary pathways of melanoma progression, from benign and dysplastic nevi (see Figure 1), linked to $N-R A S$ and $B R A F$ activation, respectively (10). In contrast to $B R A F$ mutations, $N-R A S$ mutations in melanoma appear to arise as a result of UV damage (82, 85). $N-R A S$ and $B R A F$ activating mutations in melanoma (as also occur in other tumor types) are mutually exclusive, indicating that these genes function in the same cellular growth regulatory pathway (80). A recent report (86) has found that mutations in $B R A F$ are associated with enhanced sensitivity of melanoma cells to pharmacological inhibitors of MEK compared to cells harbouring RAS mutations. These data suggest that melanoma cells carrying $B R A F$ mutations are much more dependent on MAPK signaling than $R A S$ mutant cells are, as Ras signaling can diverge through other pathways distinc to MAPK.

\subsection{PTEN and the phosphatidylinositol 3'-kinase pathway}

PTEN, one of the tumor suppessor genes most frequently mutated in cancer, encodes a lipid and protein phosphatase involved in negative regulation of the PI3K signaling pathway (87). PI3K activation by receptor tyrosine kinases (RTKs), G-protein coupled receptors or Ras proteins leads to phosphorylation of phosphatidylinositol-4, 5-biphosphate (PIP2) to phosphatidylinositol-3, 4, 5-triphosphate (PIP3). PIP3 recruits other proteins to the plasma membrane which lead to activation (phosphorylation) of Akt (also known as protein kinase B), the major effector of PI3K (Figure 4B). Activated Akt phosphorylates several targets, mediating its activation or inhibition, resulting in cell growth, survival and proliferation. In addition, PI $3 \mathrm{~K}$ has been shown to interact with other signaling pathways leading to cytoskeletal rearrangements, cell transformation and invasion (87). Pten regulates negatively the PI3K pathway by dephosphorylation of PIP3 (Figure 4B). Therefore, loss or inactivation of Pten leads to constitutive activation of PI3K signaling. PTEN germline mutations result in Cowden disease, a predisposition syndrome to several types of cancer, in which there is not an increased risk for melanoma (88). Involvement of PTEN in melanoma was suspected because loss-of-heterozygosity (LOH) of $10 \mathrm{q}$ (where the PTEN locus is located) occurs in $30-50 \%$ of sporadic melanomas (89). The region deleted at $10 \mathrm{q}$ is, however, large and could include other tumor suppressor genes (39). In addition, somatic mutations in PTEN have been found in about $10 \%$ of melanomas (90, 91). Interestingly, $P T E N$ inactivating mutations in melanoma occur in association with activating mutations in $B R A F$, but not $N-R A S$ (92). This is consistent with the fact that Ras proteins are able to activate both the PI3K and MAPK 

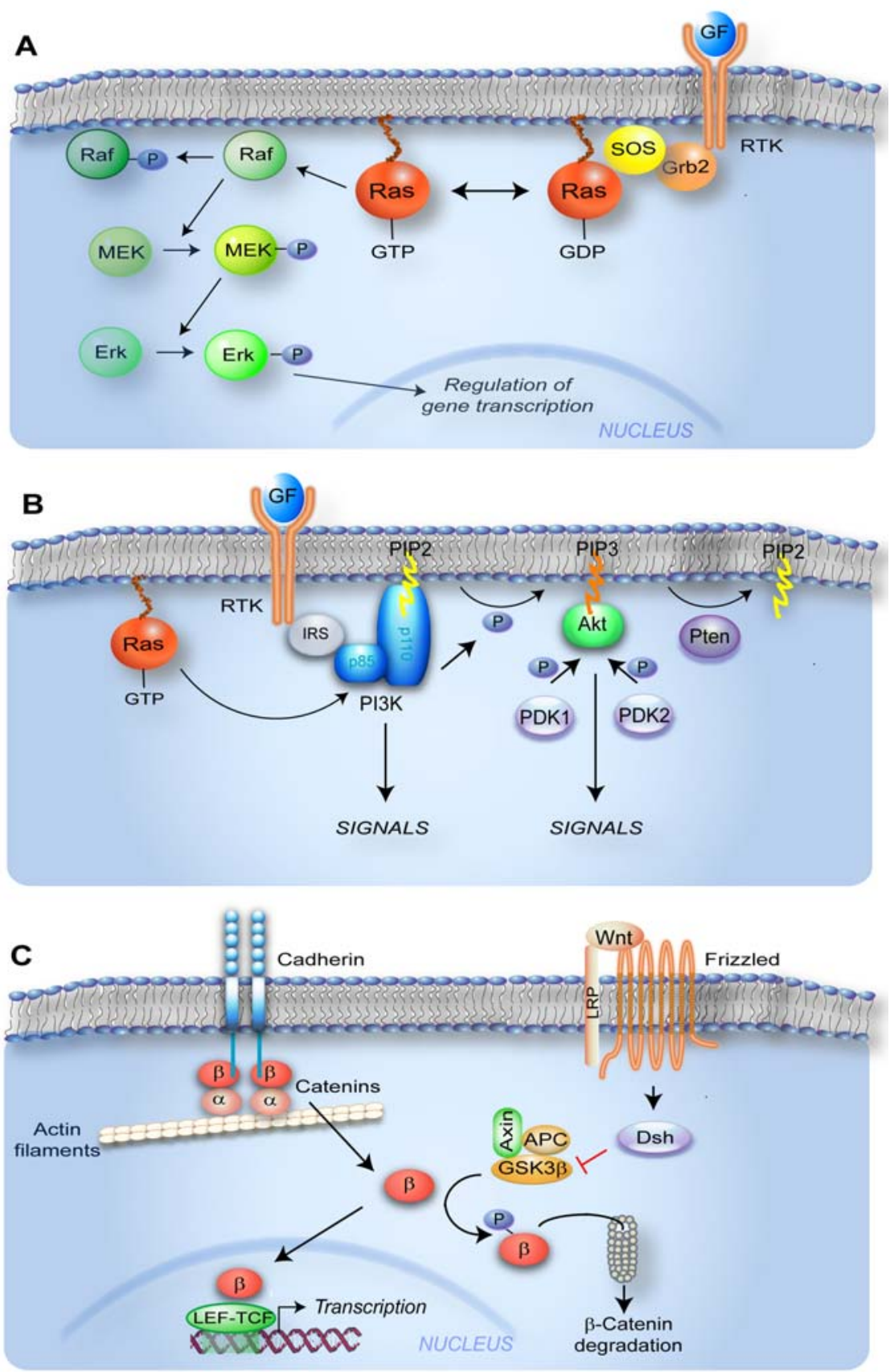

Figure 4. (A) The Ras/MAPK signaling pathway. Upon binding of growth factors (GF) to their respective receptor tyrosine kinases (RTKs), activation of RTKs stimulates the exchange of GDP for GTP on Ras. The best characterized Ras effector pathway proceeds via a kinase cascade involving the sequential phosphorylation of Raf, MEK and Erk. Activated Erks translocate into the nucleus where phosphorylate specific transcription factors. (B) The PI3K/Akt signaling pathway. Activation of RTKs, or binding of Ras to PI3K, leads to the stabilization of its membrane localization and the activation of its catalytic domain which then converts PIP2 into PIP3. PIP3 recruits Akt to the plasma membrane where it can be fully activated by phosphorylation by the kinases PDK1 and PDK2. Akt mediates the activation and inhibition of several targets resulting in cellular growth, survival and proliferation. In addition PI3K has been shown to regulate the activity of other protein targets distinct to Akt. (C) The Wnt/beta-catenin signaling pathway. In the absence of Wnt ligands, free beta-catenin in the cytoplasm is rapidly bound to the "destruction complex", phosphorylated by GSK3beta and degraded through the proteasome. When Wnt proteins bind to the G-protein coupled receptor Frizzled, GSK3beta is inhibited and then beta-catenin degradation is reduced. As beta-catenin accumulates in the cytoplasm, it enters the nucleus where binds to LEF/TCF transcription factors activating gene transcription. LRP, LDL-receptor-related protein; Dsh, Dishevelled; APC, adenomatous polyposis coli; GSK, glycogen synthase kinase; TCF, T-cell factor. 
signaling pathways. Thus, constitutive activation of N-Ras in melanoma abrogates the need for specific inactivation of Pten. In addition, a recent report has found that promoter hypermethylation leading to epigenetic silencing of PTEN is another relevant mechanism for loss of this tumor suppressor gene in melanoma (93). As a matter of fact, expression studies have found the deregulation of the PI3K signaling pathway is a common event in melanoma development. Thus, increased expression of activated Akt (phospho-Akt) was found in dysplastic nevi and metastatic melanoma with respect to benign nevi $(93,94)$. In addition, downregulation of Akt, or overexpression of Pten, in melanoma cell lines induces apoptosis (95).

\subsection{Microphthalmia-associated transcriptional factor}

Mitf is a transcription factor essential for melanocyte cell-fate determination during commitment from pluripotent neural crest stem cells (see ref. 96 for a review). As mentioned above, Mitf is the major transcriptional regulator of pigmentation enzymes, like tyrosinase, TRP-1 and DCT (Figure 3B). When mutated in mice (Mitf ${ }^{m i / m i}$ mouse) leads to complete absence of neural crest-derived melanocytes as well as defects in the retinal pigmented epithelium, mast cells and osteoclasts (97). These data suggest that Mitf is essential not only for differentiation but also for survival of melanocytes. In humans, mutations in MITF causes an autosomal inherited disease, known as Waardenburg type IIA syndrome, characterized by deafness and white hairlock. The Waardenburg type IIA syndrome arises from melanocyte deficiencies in the eye, forelock and inner ear (98). The MITF gene has a complex organization. At least nine distinct promoter-exon units direct the synthesis of specific Mitf isoforms that originate by alternative splicing (99). One isoform, Mitf-M, is specific for the melanocyte lineage due to the presence of a unique melanocyte-restricted promoter (100). Transcription factors that regulate MITF expression include CREB, SOX10, TCF/LEF-1 and Mitf itself, among others (96). alpha-MSH binds to MC1R which activates adenylate cyclase and produces cAMP (Figure 3A). cAMP leads to the phosphorylation of CREB transcription factors, which in turn activate the MITF promoter. Despite of the cAMP-CREB pathway is ubiquitous, MITF expression is cell-type specific. This is explained, at least in part, by the obligate cooperation between CREB and SOX10, which is specific for the neural crest lineage (101). TCF/LEF-1 binds beta-catenin at the point end of Wingless-type (Wnt) signaling (Figure 4C) linking MITF with the Wnt/beta-catenin signaling pathway, which is crucial for the differentiation of melanocytes from the neural crest (102-104). In addition, Mitf is regulated by post-translational mechanisms, namely by phosphorylation (Figure 3A). Nevertheless, the role of phosphorylation on Mitf activity is obscure. For example, phosphorylation of Mitf by Erk2 increases recruitment of the transcriptional coactivator p300/CBP, a CREB binding protein, and enhances MITF transcriptional activity, while simultaneously targets Mitf for ubiquitin-dependent proteolysis $(105,106)$.
Genomic amplification of MITF has been found in $10-20 \%$ of primary melanomas with a higher incidence in metastatic melanoma (107). Strong MITF gene amplification correlates with a reduced disease-specific patient survival and, therefore, MITF amplification seems to be a useful prognostic marker for metastatic melanoma $(107,108)$. In addition, functional studies on immortalized melanocytes that have inactivated the p53 and pRb pathways showed that ectopic overexpression of Mitf complemented $\mathrm{BRaf}^{\mathrm{V} 600 \mathrm{E}}$ to confer soft-agar clonogenic growth, suggesting that MITF is an oncogene in human melanoma, particularly in the setting of cell cycle deregulation and excess of MAPK signaling activation (107). In this study, MITF amplification was also associated with resistance to chemotherapy (107). However, this fact could not be confirmed in a subsequent report (108). Remarkably, other authors have found that the expression of MITF and its targets (Tyrosinase, TRP-1 and $D C T)$ are downregulated in advanced melanoma (109). Moreover, upon transformation of murine melanocytes by oncogenic $B R A F$, Mitf expression is downregulated, and reexpression of Mitf inhibits proliferation of transformed melanocytes (110). These observations support a Janusfaced role for Mitf on the development of melanoma (108), and suggest that there are distinct subsets of melanoma tumors. In some melanomas, cell survival is dependent on Mitf (106), while in others decreased expression of Mitf might provide a growth advantage by diminishing energy and oxidative stress associated with pigment production (96).

\subsection{The Wnt/beta-catenin signalling pathway}

In the human epidermis, melanocytes establish close contacts with the neighboring keratinocytes that are mediated by the cell-cell adhesion protein E-cadherin (66). In the adhesion complex, beta-catenin interacts with Ecadherin and alpha-catenin, this latter also binds to the actin cytoskeleton (Figure 4C). In epithelial cells, any betacatenin free in the cytoplasm (not bound to E-cadherin) is immediately ubiquitinated and degraded by the proteasome. Beta-catenin degradation involves the formation of a multiprotein complex with the adenomatous poliposis coli (APC) protein, axin and glycogen synthase kinase (GSK3beta). GSK3beta phosphorylates beta-catenin in serine/threonine leading to its ubiquitination and proteolysis (111). In colon cancer, inherited and somatic mutations in the tumor suppressor $A P C$ reduce the degradation of beta-catenin and cause its accumulation into the nucleus, where it interacts with DNA-bound TCF and LEF family members of transcription factors to activate the expression of target genes. Similarly, both gain-of-function mutations in phosphorylation residues of beta-catenin (encoded by the locus CTNNB1) and loss-of-function mutations in axin activate beta-catenin signaling and are linked to cancer (see ref. 112 for a review).

Wnts are secreted cystein-rich glycoproteins, from which at least 19 members are known in humans. These factors bind to target cells via two families of receptors: the Frizzled family of serpentine receptors and LDL-receptor-related proteins (LRP) 5 and 6 . Wnt proteins 
activate at least three different intracellular signaling pathways: the canonical Wnt/beta-catenin pathway, $\mathrm{Wnt} / \mathrm{Ca}^{2+}$ and Wnt/planar polarity (112). Beta-catenin signaling is activated in response to the formation of a complex containing Wnt, Frizzled and LRP. LRP receptor is then serine-phosphorylated by an unknown kinase allowing to the recruitment of axin to the plasma membrane and the activation and membrane recruitment of the phosphoprotein Dishevelled (Dsh). Dsh appears to interact with axin as well as with the "destruction complex" for beta-catenin leading to axin degradation and inhibition of GSK3beta (Figure 4C). As beta-catenin levels rise, it accumulates in the nucleus where, as mentioned above, in association with TCF/LEF proteins, activates the transcription of about 412 target genes.

The Wnt/beta-catenin signaling pathway is involved in melanocytic lineage commitment decisions of neural crest cell derivatives (113). Mitf is a developmentally Wnt/beta-catenin target gene (102), and several studies have reported upregulation of Mitf by Wnt/beta-catenin in melanocyte and melanoma cells (103, 104). A hallmark of the activation of this pathway in melanoma is the immunohistochemical observation of nuclear beta-catenin localization in about $30 \%$ of human melanomas (114), suggesting that constitutive activation of Wnt/beta-catenin signaling is a frequent event in melanoma (see ref. 115 for a review). However, although a relatively high incidence of stabilizing beta-catenin mutations have been observed in melanoma cell lines (116), mutations in beta-catenin and in other components of the pathway, such as APC, are infrequent in primary melanomas $(114,117$, 118). Therefore, at present, the molecular mechanisms involved in the deregulation of this pathway in melanocytic lesions are obscure.

\section{GENETICALLY ENGINEERED ANIMAL MODELS OF MELANOMA}

Most of the genes found to be mutated (or altered) in melanoma have been tested in animal models, particularly in mice. Thus, a large number of genetically engineered mouse models have been generated in different laboratories (reviewed in refs. 25, 96 and 119), the most significant of which are summarized in Table 1 . These mouse models have permitted to assess the requirement of genetic interactions between distinct pathways, as well as interactions of those pathways with the environment, in order to recapitulate human melanoma disease. Nevertheless, while most melanocytes in human skin are found at the epidermal basal layer and within hair follicles, mouse epidermal melanocytes are mostly located in hair follicles and rarely found in the interfollicular epidermis. Therefore, mouse and human skin are not identical and, thus, caution should be taken in order to extrapolate the observations made in mouse models to human melanoma.

The first successful melanoma mouse model was developed by targeted expression of simian virus 40 (SV40) large tumor $(\mathrm{T})$-antigen $(\mathrm{Ag})$ to melanocytes under the control of the Tyrosinase promoter (120). The Tantigen interacts with host proteins inactivating $\mathrm{pRb}$ and p53 functions in a manner reminiscent of p16Ink4a and p19Arf loss. Tyr-SV4O $T-\mathrm{Ag}^{+}$transgenic mice produced skin melanomas at low frequency that appeared late on life, although developed metastatic skin melanoma when exposed to limited UVB radiation shortly after birth (121, 122). In contrast, these transgenic mice produced highly aggressive ocular melanomas that originated spontaneously at a young age (120).

Mice knock-out for $p 16 \operatorname{Ink} 4 a$ that retain $p 19 A r f$ are predisposed to develop melanoma after initiation with the chemical carcinogen 7, 12-dimethylbenz $(a)$ anthracene (DMBA) (123). Moreover, treatment with DMBA of p16Ink4a-deficient mice that were heterozygous for $p 19 A r f$ resulted in increased incidence of cutaneous melanoma that produced frequent metastasis (124). These studies have provided compelling evidence that inactivation of both the $\mathrm{pRb}$ and $\mathrm{p} 19 \mathrm{Arf} / \mathrm{p} 53$ pathways are crucial for development of melanoma. The cooperation between these two pathways and that of PI3K-Akt has been evaluated in compound mutant p16Ink4a/p19Arf-deficient mice heterozygous for Pten. These mice spontaneously developed a wide spectrum of tumor types including melanoma (125). DMBA was also able to enhance melanomagenesis in mice harbouring a $C d k 4$ mutation that inactivates the $\mathrm{pRb}$ pathway, as found in familial melanoma $(40,126)$.

A large number of Ras transgenic mouse models for melanoma have been developed in the past years, most of which express an activated form of the H-Ras gene. Adult transgenic mice expressing an $H-R_{a s}{ }^{V 12 G}$ oncogene in melanocytes have been chronically exposed to either UVB irradiation or DMBA. Both challenges produced melanoma, but at low efficiency (127). Of note, DMBA, a chemical agent of unknown environmental relevance for human melanoma, was most efficient than UV to induce melanoma in this and other mouse models (see Table 1). Loss of either p16Ink4a or p19Arf (or Trp53 encoding p53) in $T y r-H-R_{a s}{ }^{V 12 G+}$ transgenic mice induced spontaneous skin melanomas with high incidence $(128,129)$. The cooperation between UV irradiation and the loss of each Cdkn2a encoding tumor suppressor gene was also examined in $\mathrm{H}$-Ras ${ }^{+}$transgenic mice (130). The results of these studies show that loss of p19Arf, but not of p16Ink4a, cooperates with UVB exposure to accelerate melanoma development. Tumors arising in UVB-irradiated $\mathrm{H}-\mathrm{Ras}^{+}$/ p19 $\mathrm{Arf}^{/-}$mice showed either loss of p16Ink4a or Cdk6 amplifications (both leading to disruption of the $\mathrm{pRb}$ pathway), these data indicate a joint cooperation between mutations at both $\mathrm{p} 53$ and $\mathrm{pRb}$ pathways and $\mathrm{UV}$ irradiation for UV-induced melanomagenesis. An additional mouse melanoma model null for the $C d n k 2 a$ locus in which the $H$-Ras ${ }^{V 12 G}$ oncogene is expressed in a doxycycline-inducible manner showed that H-Ras activation was essential not only for melanomagenesis but also for melanoma maintenance (131). However, the $\mathrm{H}$ $\mathrm{Ras}^{+}$transgenic mouse models have some limitations to emulate the human disease, as tumors are non-pigmented and no metastasis is found in these animals (Table 1). Since $H-R A S$ mutations are rare in human melanoma compared with $N-R A S$ mutations (see above), it was extremely valuable the generation of a transgenic mouse model 
Table 1. Genetically engineered melanoma mouse models

\begin{tabular}{|c|c|c|c|c|}
\hline Transgene & Knock-out & $\begin{array}{l}\text { Carcinogen } \\
\text { exposure }\end{array}$ & Tumor phenotype/Comments & Reference \\
\hline \multirow[t]{2}{*}{ Tyr-SV40 $\mathrm{T}_{-} \mathrm{Ag}^{+}$} & \multirow[t]{2}{*}{ - } & - & $\begin{array}{l}\text { Hypopigmentation; low penetrance skin melanoma; metastatic eye } \\
\text { melanoma. }\end{array}$ & 120 \\
\hline & & UV & $\begin{array}{l}\text { Short term, neonatal, UVB exposure induced melanocytic skin lesions } \\
\text { and metastatic melanoma. }\end{array}$ & 121,122 \\
\hline \multirow[b]{3}{*}{ - } & p16Ink4a & DMBA & Low penetrance skin melanoma. & 123 \\
\hline & p16Ink4a $a^{-/,}$, p19 Arf $^{+/-}$ & DMBA & Metastatic skin melanoma. & 124 \\
\hline & pl6Ink4a $a^{-1 /}$ p19Arf $^{/-}$, Pten $^{+/-}$ & - & Low penetrance skin melanoma. & 125 \\
\hline \multirow[b]{2}{*}{$\operatorname{Cdk} 4(R 24 C)^{+}$} & 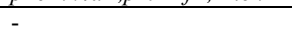 & - & Low penetrance skin melanoma. & 126 \\
\hline & & $\begin{array}{l}\mathrm{DMBA} / \mathrm{TP} \\
\mathrm{A}\end{array}$ & High penetrance skin melanoma, no metastasis. & 40 \\
\hline \multirow{6}{*}{$M T-H G F / S F^{+}$} & & - & Low penetrance metastatic skin melanoma & 133,134 \\
\hline & - & UV & $\begin{array}{l}\text { Single, neonatal, UVB exposure (but not UVA exposure) enhanced } \\
\text { melanomagenesis; chronic adult UVB exposure had no effect. }\end{array}$ & $135-137$ \\
\hline & pl6Ink4a & UV & $\begin{array}{l}\text { Single neonatal UVB exposure induced skin melanoma (mean onset age } \\
\text { of } \sim 7 \text { months). }\end{array}$ & 56 \\
\hline & $p 19 \mathrm{Arf}^{-1}$ & UV & $\begin{array}{l}\text { Single neonatal UVB exposure induced skin melanoma (mean onset age } \\
\text { of } \sim 3.5 \text {. months). }\end{array}$ & 56 \\
\hline & p16Ink4a $a^{-/ .}, p 19 \operatorname{Arf}^{-/-}$ & UV & $\begin{array}{l}\text { Both loss of p16Ink } 4 \mathrm{a} / \mathrm{p} 19 \text { Arf function and single, neonatal, UV } \\
\text { exposure enhanced melanomagenesis. }\end{array}$ & 138 \\
\hline & $\operatorname{Trp} 53^{-/ 2}$ & UV & Single neonatal UVB exposure did not induce melanocytic lesions. & 56 \\
\hline \multirow{6}{*}{ Tyr-HRasV12G ${ }^{+}$} & - & DMBA/UV & $\begin{array}{l}\text { No spontaneous skin tumors without carcinogen; each carcinogen } \\
\text { induced melanoma; DMBA was superior to chronic adult UVB } \\
\text { exposure. }\end{array}$ & 127 \\
\hline & \multirow[t]{2}{*}{ p16Ink4a ${ }^{-/}$} & - & High penetrance, nonmetastatic skin melanoma. & 128,129 \\
\hline & & UV & $\begin{array}{l}\text { Single, neonatal, UVB exposure had no impact in melanoma } \\
\text { development. }\end{array}$ & 130 \\
\hline & \multirow[t]{2}{*}{$p^{p 19 A r f^{-1-}}$} & - & High penetrance, nonmetastatic skin melanoma. & 128,129 \\
\hline & & UV & Single, neonatal, UVB exposure accelerated melanomagenesis. & 130 \\
\hline & $\operatorname{Trp} 53^{\%}$ & - & High penetrance, nonmetastatic skin melanoma. & 128,129 \\
\hline \multirow[t]{2}{*}{ Tyr-NRasQ16K } & - & - & Hyperpigmentation, low penetrance, metastatic skin melanoma. & 132 \\
\hline & p16Ink4a $a^{-/}$, p19Arf ${ }^{-/ /}$ & - & High penetrance, metastatic skin melanoma. & 132 \\
\hline
\end{tabular}

DMBA: 7, 12-dimethylbenzanthracene; TPA: 12-O-tetradecanoylphorbol-13-acetate

expressing an activated $N$-Ras ${ }^{Q 61 K}$ oncogene (132). The Tyr-N-Ras ${ }^{Q 61 K+}$ transgenic mice had hyperpigmented skin and developed cutaneous metastasizing melanomas. Moreover, on a pl6Ink4a/p19Arf-deficient background, these transgenic mice had accelerated melanomagenesis and developed metastatic melanoma with high penetrance (132).

Interactions between receptor tyrosine kinase signaling and UV irradiation have been investigated in the $M T-H G F / S F^{+}$transgenic mouse model in which the cytokine $\mathrm{HGF} / \mathrm{SF}$ is expressed under the control of the ubiquitous metallothienin-1 (MT) promoter. These mice develop melanomas, but after long latency periods (133, 134), suggesting that additional genetic alterations are needed for melanoma development. A single neonatal dose of UVB radiation was sufficient to induce melanoma lesions with high penetrance and short latencies in MT$H G F / S F^{+}$transgenic mice, while chronic UVB exposure in adult mice had no effect $(135,136)$. This model was also useful to demonstrate that it is the UVB portion of the sunlight spectrum and not UVA responsible for initiation of melanoma (137). The response of these mice is in accordance with epidemiological studies in humans suggesting that melanoma is caused by intense intermittent exposure to UVB during childhood, rather than cumulative sun exposure during adulthood, as mentioned above $(2,4)$. The cooperation between neonatal UVB irradiation and inactivation of the $C d n k 2 a$ locus has been further demonstrated in $H G F / S F^{+}$transgenic mice. UVB-irradiated $\mathrm{HGF} / \mathrm{SF}^{+} / \mathrm{p} 16 \operatorname{Ink} 4 \mathrm{a}^{-/ /} / \mathrm{p} 19 \mathrm{Arf} / \mathrm{f}^{/-}$mice exhibited a significant acceleration of melanoma development with respect to untreated mice and UVB-irradiated $H G F / S F^{+}$mice with an intact Cdkn2a locus (138). Interestingly, $H G F / S F^{+}$ transgenic mice in which either one or both Trp53 alleles were inactivated failed to develop melanocytic lesions after neonatal UVB irradiation. In contrast, $H G F / S F^{+}$mice deficient for p19Arf developed melanoma with a mean onset age of about 3.5. months (57). These data suggest that although p19Arf and p53 proteins are linked in a common pathway, it is the loss of p19Arf function which is critical for the development of melanoma. Moreover, experiments with cultured cells showed that unlike fibroblasts, where p19Arf can only trigger cell growth arrest and senescence in the presence of a functional p53, p19Arf regulate melanocyte senescence in a p53-independent manner (57).

Melanoma genetic models also include animals distinct from the mouse, such as zebrafish and Xiphophorus fish. Thus, while there has been no report to date on a BRaf transgenic mouse model for melanoma, it has been shown that activating mutations of $B R a f$ in zebrafish, which leads only to development of benign nevi, cooperate with inactivation of p53 for melanoma development (139). In Xiphophorus fish, activating mutations in Xmrk, the EGFR homolog, enhances melanoma susceptibility (140, 141). This observation is interesting, as no activating mutations in EGFR have been found in human melanoma. However, it is in agreement with a number of studies on melanoma cell lines demonstrating that sustained activation of the EGFR signaling pathway provides potent autocrine survival signals for $R A S$-driven melanoma tumorigenicity (25). 


\section{GENOMIC AND GENE EXPRESSION PROFILING STUDIES}

As described in the Introduction section, it is clear that melanoma is a heterogeneous clinical and histopathological entity. Recent studies using genomic high-throughput screening techniques have shed new light on the molecular events associated with the heterogeneity of melanoma (142-146). These techniques that enable the analysis of the expression of multiple genes in large series of tumor samples have begun to build a new molecular classification strategy of melanoma and have led to the identification of novel genes associated with melanoma progression. In this section, we review the results of expression studies using cDNA or tissue array technologies, as well as those from accurate quantification of DNA copy number variation by using comparative genomic hybridization (CGH).

\subsection{Gene expression profiles}

Most of gene expression analyses on melanoma have been performed on cell lines. Some studies used cell lines with different aggressiveness or metastatic behaviour (147, 148), while others attempted to define gene profiles that are regulated by oncogenic $B R A F$ or $N-R A S$, or induced by UVA or UVB radiation, or even related to the different sensitivity of cell lines to the treatment with interferons (reviewed in refs. 75, 142 and 149). The results of these studies failed to fulfil the expectations in order to identify a molecular signature for melanoma metastasis or to discover potential targets for new therapeutic options, but they represented a stimulus for further analyses, strikingly on primary melanomas. A recent report on primary melanomas (150) showed that the gene profile of a subgroup of metastatic melanomas matched that of RGP melanoma, suggesting the possibility that melanoma can metastasize even in the radial phase of growth. Molecular signatures of invasive cutaneous (151) and uveal (152) melanoma have also been reported. More recently, some reports used large-scale gene expression profiling analyses on primary human melanomas from patients with long clinical follow-up (153-155). However, in these studies, comparison was limited almost exclusively to VGP melanoma and metastatic melanoma and, therefore, the genes identified may be associated with the latest stage of melanoma progression. Overall, the results of these gene expression analyses suggest that progression to metastatic melanoma implies dysregulation of clusters of genes involved in cell cycle, apoptosis, immune response, metabolism, signal transduction, transcriptional regulation, protein synthesis and degradation, remodelling of the extracellular matrix and epithelial-mesenchymal transition (EMT). We summarize the most important results of these analyses in Table 2 .

The panel of genes presented in Table 2 include products related to cell cycle regulation, mitosis and DNA replication, such as the proliferation cell nuclear antigen (PCNA), cell division cycle 6 (Cdc6) and Cdc28/Cdk1 protein kinase regulatory subunit 2 , all of them overexpressed in metastatic melanoma and linked to poor prognosis $(153,155)$. Particularly interesting is the finding that high levels of geminin and minichromosome maintenance (MCM) proteins are associated with high risk of melanoma metastasis and death (153). These proteins are involved in the control of DNA replication and genomic stability during cell cycling. Geminin controls that genomic DNA is fully replicated only once during each cell division by inhibiting the replication licensing factor Cdt1, thus avoiding that MDM proteins, which unwind DNA at replication origins, are further recruited to these sites (156). Other cell cycle-related products upregulated during melanoma progression are the subunit gamma of the eukaryotic translation initiation factor 2 (eIF2gamma) and the ubiquitin conjugation enzyme E2I (UBE2I), this latter involved in the ubiquitination and degradation pathway of cell cycle regulatory proteins. eIF2gamma seems to be transiently upregulated in melanomas with respect to nevi and metastasis and may contribute to develop autonomous melanoma growth, while UBE2I is progressively upregulated in melanomas and metastases in comparison with nevi (157). A recent report from the same laboratory has found upregulation of the ataxia telangiectasia-mutated (ATM) protein kinase in nodular malignant (VGP) melanoma and deep penetrating nevi, a variant of benign melanocytic nevus with clinical and histological features mimicking VGP melanoma (158). ATM plays a central role in the DNA damage response and is involved in cell cycle control and DNA repair (159). In addition, a number of pro-apoptotic genes, including the member of the forkhead box gene family $F O X Q 1$, the gene encoding tumor protein p73-like $(T P L 73 L)$ as well as members of the tumor necrosis factor (TNF) receptor superfamily and ligands have been found to be downregulated during the transition from non-invasive RGP melanoma to the potentially metastatic VGP melanoma (160). The same occurs with members of the caspase and calpain families, indicating an important role for loss of apoptotic mechanisms in melanoma progression (160).

Several reports point to a significant group of genes dysregulated in invasive melanoma which are involved in EMT. EMT is the process by which epithelial cells lose their polarity, loose cell-cell contacts with neighbouring cells, reorganize their cytoskeleton and express mesenchymal markers. Consequently, these tumor cells become motile and interact with the extracellular matrix, invading surrounding tissues and acquiring the capacity to metastasize (161). Although melanoma cells are not epithelial in nature, these EMT genes (that were previously identified as a determinant of local invasion and metastasis in carcinomas) also appear to be relevant for malignant melanoma. For instance, the cadherin switch by which loss of epithelial E-cadherin is associated with gain of neural N-cadherin during progression to metastatic melanoma $(154,155,162)$ is supported by experimental approaches with melanoma cell lines (163-165). Increased $\mathrm{N}$-cadherin expression in VGP melanoma favours cell-cell contacts of melanoma with stromal cells and enhances survival of melanoma cells by stimulating beta-catenin signaling (166). Overexpression of N-cadherin in metastatic VGP melanoma also matches with downregulation of cadherin 10, a type II cadherin with 
Table 2. Gene expression signatures in melanoma tumor progression

\begin{tabular}{|c|c|c|c|c|c|c|}
\hline Accession & Gene name & Protein & Function & Expression & Commentary & Reference \\
\hline & $\begin{array}{l}\text { Cell cycle- } \\
\text { related genes }\end{array}$ & & & & & \\
\hline NM_001415 & EIF2 gamma & EIF2 subunit gamma & DNA translation & Up & Tumour progression & 157 \\
\hline NM_003345 & UBE2I & $\begin{array}{l}\text { Ubiquitin-conjugating } \\
\text { enzyme E2I }\end{array}$ & $\begin{array}{l}\text { Ubiquitine pathway, G1/S } \\
\text { control }\end{array}$ & Up & Tumour progression & 157 \\
\hline NM 015895 & $G M N N$ & Geminin & DNA replication inhibitor & Up & High risk of metastasis & 153 \\
\hline NM 002592 & $P C N A$ & PCNA & Cofactor DNA polymerase & $\mathrm{Up}$ & Genome destabilization & 153 \\
\hline $\begin{array}{l}\text { NM_002388 } \\
\text { NM_005914 } \\
\text { NM_005915 }\end{array}$ & $M C M 3,4,6$ & MCM components $3,4,6$ & DNA replication & Up & High risk of metastasis & 153 \\
\hline NM 001254 & CDC6 & CdC6 & Cell cycle control & $\mathrm{Up}$ & Poor prognosis & 155 \\
\hline NM_001827 & $C K S 2$ & $\begin{array}{l}\text { Cdc28/Cdk1 protein kinase } \\
\text { subunit } 2\end{array}$ & Cell cycle control & $\mathrm{Up}$ & Poor prognosis & 155 \\
\hline \multirow[t]{2}{*}{ NM_000051 } & $A T M$ & ATM kinase & $\begin{array}{l}\text { DNA damage response. } \\
\text { Cell cycle control }\end{array}$ & Up & $\begin{array}{l}\text { Associated with } \\
\text { melanocytic infiltration }\end{array}$ & 158 \\
\hline & $\begin{array}{l}\text { EMT-related } \\
\text { genes }\end{array}$ & & & & & \\
\hline NM_004360 & $\mathrm{CDHI}$ & E-cadherin & Cell-cell adhesion & Down & Tumour progression & $\begin{array}{ll}154, & 155, \\
162 & \\
\end{array}$ \\
\hline NM_001793 & $\mathrm{CDH} 3$ & P-cadherin & Cell-cell adhesion & Down & Tumor progression & 150,162 \\
\hline NM $\quad 006727$ & $\mathrm{CDH10}$ & Cadherin-10 & Cell-cell adhesion & Down & High risk of metastasis & 154 \\
\hline NM_001792 & $\mathrm{CDH} 2$ & N-cadherin & Cell-cell adhesion & Up & Melanoma invasiveness & 154,162 \\
\hline NM 001795 & $\mathrm{CDH5}$ & VE-cadherin & Cell-cell adhesion & Up & Tumor progression & 167 \\
\hline NM 004431 & EPHA2 & Ephrin receptor EphA2 & Cell signaling & $\mathrm{Up}$ & Tumour progression & 154,168 \\
\hline $\begin{array}{l}\text { NM_002421 } \\
\text { NM_004530 }\end{array}$ & $M M P-1,-2$ & $\begin{array}{l}\text { Matrix metalloproteinases } 1 \\
\text { and } 2\end{array}$ & $\begin{array}{lr}\begin{array}{l}\text { Degradation of } \\
\text { extracellular matrix }\end{array} & \text { the } \\
\end{array}$ & Up & Tumour progression & 169 \\
\hline NM_000582 & SPPI & Osteopontin & MMP's inductor & Up & High risk of metastasis & 154,155 \\
\hline NM_003118 & SPARC & Osteonectin & Angiogenesis & Up & Tumour progression & 154 \\
\hline NM_003392 & WNT5A & Wnt5a & Cell signalling & $\mathrm{Up}$ & Melanoma invasiveness & 151,171 \\
\hline NM_004948 & $D S C 1$ & Desmocollin 1 & Desmosomal component & Down & Loss off cell adhesion & 155 \\
\hline & Others genes & & & & & \\
\hline NM_001922 & $D C T$ & Dopachrome tautomerase & Melanin synthesis & Up & Tumour progression & 157 \\
\hline NM_000245 & $H G F R(c-M E T)$ & HGF/SF receptor & Cell signaling & Up & Tumor progression & 172 \\
\hline NM 002266 & KPNA2 & karyopherin alpha 2 & Nuclear import of proteins & Up & Poor prognosis & 153 \\
\hline
\end{tabular}

similar binding strength than E-cadherin (154). Moreover, P-cadherin, another important cell-cell adhesion receptor for the interaction of melanocytes with keratinocytes, was also found to be downregulated or lost in malignant melanoma $(150,162)$. Conversely, microarray analyses on cell lines revealed that the typical cell-cell adhesion receptor for endothelial cells, VE-cadherin, is dramatically overexpressed in aggressive cutaneous and uveal melanoma cells (167-169). The finding that VE-cadherin is overexpressed in malignant melanoma cells together with other key molecules involved in the formation of vasculogenic-like networks, such as EphA2 and laminin 5gamma2 (168) allowed Hendrix and colleagues to introduce the term of "vasculogenic mimicry". EphA2 is a member of the ephrin tyrosine kinase family of receptors while laminin 5gamma 2 is a component of the extracellular matrix (169). The concept "vasculogenic mimicry" describes the plasticity and unique ability of aggressive melanoma cells to form tubular structures and patterned networks in three-dimensional cultures that mimic embryonic vasculogenic networks (170). Osteopontin, a secreted phosphoprotein that promotes antiapoptotic signals as well as angiogenesis, and the expression of matrix metalloproteinases (MMPs) and osteonectin (SPARC), a secreted extracellular matrix protein involved in tumor cell migration, invasion and angiogenesis, were also found to be upregulated in aggressive melanomas $(154,155)$. These proteins are associated with melanoma cell migration/invasion by inducing specific interactions between tumor and stromal cells and contributing to remodel the extracellular matrix. The collagenases MMP-1 and MMP-2 are overexpressed in aggressive with respect to poorly aggressive melanoma cell lines (169), and MMP-2 and ADAM9 (disintegrin and metalloproteinase domain 9) were found to be upregulated in metastatic VGP melanoma (154). Remarkably, Wnt5a, a member of the Wnt family of secreted factors, has also been associated with melanoma cell migration and invasion. The Wnt5a protein signals via a non-canonical Wnt pathway to activate phospholipase C, causing phospholipids turnover in the membrane, releasing calcium from intracellular stores and increasing the activity of PKC (112). Overexpression of Wnt5a has been found in melanoma tumors and cell lines associated with increased motility and invasiveness and poor clinical outcome (151, 171). It is thought that Wnt5a contributes to melanoma progression through its activation of PKC (171).

Microarray technology was also useful to confirm that the MAPK pathway is activated in metastatic melanoma, as the HGF/SF receptor (c-Met) and other components of the HGF/SF-activated MAPK pathway were significantly upregulated in melanoma metastases and melanoma cell lines compared with normal melanocytes (172).

\subsection{Comparative genomic hybridization}

High-resolution genomic techniques to scan extensive chromosomal rearrangements are providing valuable results in melanoma. This type of integrated 
Table 3. Summary of chromosomal alterations involving known genes found in melanoma

\begin{tabular}{|c|c|c|c|c|}
\hline Chromosomal aberrations & Gene candidate & Protein & Commentary & Reference \\
\hline \multicolumn{5}{|l|}{ Gains/amplifications } \\
\hline $3 \mathrm{p} 14$ & MITF & Mitf & $\begin{array}{ll}\begin{array}{l}\text { Cutaneous } \\
\text { melanomas }\end{array} & \text { malignant } \\
\end{array}$ & 107,173 \\
\hline 7q21.3.-qter & $B R A F$ & Braf & Cutaneous melanomas & 64,173 \\
\hline $8 \mathrm{q} 23$-qter & $c-M Y C$ & c-Myc-1 & $\begin{array}{l}\text { Primary and metastatic } \\
\text { cutaneous and ocular } \\
\text { melanomas }\end{array}$ & $64,174-176$ \\
\hline $11 \mathrm{p}$ & HRAS & H-Ras & Spitz nevi & 177,178 \\
\hline $11 \mathrm{q} 13$ & $C C N D 1$ & cyclin D1 & $\begin{array}{l}\text { Acral and mucosal } \\
\text { melanomas }\end{array}$ & 80 \\
\hline $12 \mathrm{q} 14$ & CDK4 & Cdk4 & $\begin{array}{ll}\begin{array}{l}\text { Acral and } \\
\text { melanomas }\end{array} & \text { mucosal } \\
\end{array}$ & 80 \\
\hline $18 \mathrm{q}$ & $\mathrm{CDH} 2$ & N-cadherin & $\begin{array}{l}\text { Metastatic cutaneous and } \\
\text { uveal melanomas }\end{array}$ & 174,179 \\
\hline \multicolumn{5}{|l|}{ Losses } \\
\hline $1 \mathrm{p} 31$ & $I T G B 3 B P$ & beta 3 endonexin & Uveal melanomas & 180 \\
\hline $9 \mathrm{p}$ & $C D K N 2 A$ & p16Ink4a/p14Arf & $\begin{array}{l}\text { Primary and metastatic } \\
\text { melanomas }\end{array}$ & 64,80 \\
\hline $10 \mathrm{q}$ & PTEN & Pten & $\begin{array}{l}\text { Primary and metastatic } \\
\text { melanomas }\end{array}$ & $64,80,174$ \\
\hline
\end{tabular}

genomic approach led to the identification of MITF as an oncogene amplified in melanoma $(107,173)$. Also, Curtin and co-workers afforded the first consistent molecular classification of melanoma by comparing genome-wide alterations in the number of copies of DNA and mutational status of $B R A F$ and $N-R A S$ in melanomas differing in the degree of UV light exposure (80). This latter study provided the definitive proof that melanoma is a genetically heterogeneous disease (144). Acral (palms and soles) and mucosal melanomas exhibited higher genetic instability, with abundant chromosomal gains and losses, intrachromosomal copy number changes and focal amplifications, than melanomas arising on skin with chronic or intermittent sun exposure. In addition, the mutational spectrum in $N-R A S$ and $B R A F$ was different between melanomas from sun-exposed and sun-protected skin (see above). Gains/amplification of CCND1, the gene located on chromosome 11q13 that encodes cyclin D1, inversely correlated with mutations in $B R A F$ independently of the type of melanoma. Amplifications of CDK4 (located on chromosome 12q14), which encodes a cyclin D1 binding partner, were more common in acral and mucosal melanomas than in melanomas arising in sun-exposed skin, and did not were observed in tumors with mutations in either $B R A F$ or $N-R A S$, or in tumors which had amplification of CCND1 (80). Interestingly, the most commonly lost genomic region in melanomas is $9 p$ containing the $C D K N 2 A$ locus $(64,80)$. In the study by Curtin and co-workers, losses of $C D K N 2 A$ were more common in acral and mucosal melanomas, and homozygous deletions of $C D K N 2 A$ occurred exclusively in tumors without $C D K 4$ amplifications. In a former study by Bastian and colleagues, losses of chromosomes 9 and 10 occurred early on in melanoma progression (RGP melanoma), whereas gains of chromosome 7 containing $B R A F$ occurred later (64). Loss of chromosome 10 containing the PTEN tumor suppressor gene is another frequent genetic alteration found in acral and mucosal melanomas as well as in melanomas arising as a consequence of intermittent sun exposure, and correlates positively with mutations in $B R A F(80)$. These data are consistent with observations made by other laboratories (see above). Table 3 summarizes the most significant chromosomal alterations found in melanoma that involve well known candidate genes. Overrepresentation of 8q23qter harbouring $c-M Y C$ and amplification of this oncogene by fluorescence in situ hybridization (FISH) have been detected in primary and metastatic cutaneous melanoma (174). Interestingly, gain of this region is the most frequent genetic change found in uveal (ciliary body and chroid) and ocular melanoma $(175,176)$. According to a recent study, the most powerful predictor of poor prognosis in uveal melanoma is gain of $18 \mathrm{q} 11.2$ (179). Gains of $18 \mathrm{q}$ were also found in cutaneous melanoma associated with metastasis (174). Interestingly, the 18q11.2 region harbors the $\mathrm{N}$ cadherin gene which, as already mentioned, is overexpressed in cutaneous VGP and metastatic melanoma. Another common genetic alteration detected in uveal melanoma is $\mathrm{LOH}$ of $1 \mathrm{p} 31$ harboring the gene encoding beta3-endonexin, which binds to the cytoplasmic tail of beta3 integrins and modulates integrin function (180). Gains of $11 \mathrm{p}$ have been found in a subset of Spitz nevi or "juvenile melanoma", a benign melanocytic tumor typical of childhood with histopathological characteristics of melanoma that usually have a normal chromosomal complement at the level of $\mathrm{CGH}$ (177). A candidate oncogene on $11 \mathrm{p}$ is $H-R A S$, as the majority of Spitz nevi with increased copy number of chromosome $11 \mathrm{p}$ show activating mutations in the $H-R A S$ locus (178). As these and other reported genomic alterations occurring in melanoma contain large chromosomal regions, much work is needed in order to identify other candidate genes whose implication in melanoma can be validated by functional experimental strategies.

\section{MELANOMA STEM CELLS}

Stem cells are self-renewal cells that have the ability to differentiate into various cell lineages. Stem cells are located in restrictive environments, called niches, and interactions between stem cells and their microenvironment are crucial to the self-renewal process. Stem cells, though highly clonogenic, are relatively quiescent or slow cycling in response to survival and proliferation stimuli. Due to this infrequently dividing nature, stem cells are characterized as label-retaining cells when incorporate DNA synthesis 
labels such as tritiated thymidine or bromodeoxyuridine (181). Stem cells divide asymmetrically giving rise to one daughter cell that remains as a stem cell (self-renewal) and another daughter cell that rapidly divides and differentiate. Melanocytes found in the skin and in the choroid layer of the eye derive from the neural crest, a transitory structure formed at the dorsal borders of the neural plate during development of vertebrates. Neural crest cells undergo an EMT to migrate along definite pathways in the embryo. They stop at different locations to give rise to a large array of differentiated cells including peripheral neurons and glia, endocrine and cartilage cells and melanocytes (182). Melanocytic precursors, melanoblasts (unpigmented cells with the potential to produce melanin) invade all skin areas and differentiate into melanocytes. How neural crest cells become committed to the melanocytic lineage and which are the factors controlling survival, proliferation and differentiation of melanocyte precursors are still not completely clear. The analysis of mouse white spotting mutants allowed to the identification of stem cell factor (SCF, also denominated as steel factor) and its tyrosine kinase receptor c-Kit as crucial components of a pathway required for survival and migration of pigment precursors (183). Other studies characterized the implication of endothelins, a family of vasoactive peptides that bind to Gprotein-coupled receptors (184), in the development of subsets of neural crest-derived cell types, including melanocytes. In particular, endothelin-3 appears to be required together with $\mathrm{SCF} / \mathrm{c}-\mathrm{Kit}$ for migration of early melanoblasts in the dermis (reviewed in ref. 182). c-Kit signaling is known to regulate Mitf activity via the MAPK pathway (185). As aforementioned, Mitf is a key transcription factor for melanocyte development and survival. Another pathway likely involved in melanocytic development is Wnt/beta-catenin that controls neural crest cell fate and also activates Mitf expression $(102,113)$. In fact, Fang and colleagues (186), using a combination of Wnt3a, endothelin-3 and SCF, were able to derive melanocytes from human embryonic stem cells. These melanocytes were able to migrate to the epidermal basal layer in reconstituted skin.

A population that fulfils the criteria for melanocyte stem cells was identified by Nishimura and coworkers in the lower permanent portion of mouse hair follicles (187). However, it is unknown whether this cell population is multipotent or restricted to the melanocytic lineage. Interestingly, a population of multipotent adult stem cells, that gives rise to differentiated smooth muscle cells, neurons and melanocytes, has been isolated from human hair follicles (188). Notch signaling was demonstrated to exert a key role in the survival of murine melanocyte stem cells and embryonic melanoblasts, likely by inhibiting apoptosis $(189,190)$. Notch regulates an enormous diversity of developmental processes and its dysfunction is implicated in many cancers (191). In melanoma, constitutive activation of the Notch pathway has been involved in both the early transformation of melanocytes into melanoma and in the acquisition of the metastatic phenotype (reviewed in ref. 190). The oncogenic effect of Notch in melanoma appears to be mediated by activation of beta-catenin signaling (192), although constitutive Notch activation also regulates MAPK and PI3K/Akt pathways in human melanoma cells (190). Inhibitors of Notch induce apoptosis in melanoma cell lines, but not in normal melanocytes (193). It has been suggested this fact as indicative of the existence of a melanoma stem cell population, since Notch appears to be required for the maintenance and survival of melanocyte stem cells (190).

The cancer stem cell theory suggests that cancer originates from a minor subpopulation of neoplastic stem cells that hold the potential of self-renewal and are entirely responsible for sustaining the tumor and for giving rise to proliferating but progressively differentiating cells that contribute to the cellular heterogeneity of the tumor (194). Cancer stem cells may arise from adult undifferentiated stem cells or from differentiated cells that have acquired stem cell characteristics. A large body of evidence suggests that aggressive melanoma cells acquire, like embryonic stem cells, a multipotent, plastic phenotype (195). Bittner and colleagues were the first to show that aggressive melanoma cells express genes associated with different cell types, including those of endothelial, epithelial, fibroblastic, hematopoietic, neuronal and progenitor cells (151). Moreover, melanocytic-specific genes are downregulated in metastatic melanomas. Thus, pigmentation-related genes, such as MLANA (melan-A) and Tyrosinase are dramatically reduced in aggressive melanomas with respect to their poorly aggressive counterparts (195). A nice example of melanoma plasticity is the aforementioned "vasculogenic mimicry" by which aggressive melanoma cells express endothelial-associated genes and form extravascular fluid-conducting networks that allow them to adapt to the hypoxic microenvironment of rapidly growing tumors $(170,195)$. Cells with stem celllike features, such as the ability to grow as nonadherent cell aggregates (called spheres or spheroids), have been isolated from different melanoma cell lines (196). Spheroid cells were able to self-renew and differentiate into melanogenic, adipogenic, chondrogenic, and osteogenic lineages. A subset of spheroid cells expressed the cell surface marker CD20, a product identified by gene expression profiling studies as part of the molecular signature of aggressive melanomas (151). CD20 is a standard therapeutic target for treatment of non-Hodkin's lymphomas (197), which opens the possibility of being used as a potential target for treatment of melanoma as well. Also, a subset of melanoma cells with features of stem cells and resistant to doxorubicin was found to express $\mathrm{ABCB}$, a novel member of the $\mathrm{ABC}$ superfamily of active drug transporters (198). This observation points to $\mathrm{ABCB} 5$ as a potential target to increase the poor efficacy of cytotoxic compounds in melanoma.

These and other studies demonstrated that aggressive melanoma cells share many characteristics with embryonic progenitors. Stem cells have a complex relationship with their microenvironment which exerts a crucial role in determining cell fate of embryonic progenitors. In cancer, the evidence accumulated over the last decades support a major role for stromal components in all stages of tumorigenesis including initiation, progression 
and metastasis (199). The importance of the microenvironment on malignant progression was guessed by Stephen Paget over a century ago with the formulation of his "seed and soil" hypothesis (200). This hypothesis predicts that metastatic cancer cells will only colonize soils (organs) that are permissive to growth while other tissues will not support such growth (201). Lastly, a number of laboratories have shown that an embryonic microenvironment has the capacity to reverse the metastatic phenotype of cancer cells. Thus, several studies have documented that embryonic microenvironments of human embryonic stem cells, the zebrafish and the chick embryos (that are able to differentiate a stem cell lineage) reprogram aggressive melanoma cells towards a less aggressive phenotype (reviewed in ref. 195). Furthermore, these studies have uncovered Nodal, an embryonic morphogen belonging to the TGF-beta family, as an important factor for sustaining melanoma aggressiveness and plasticity. Nodal expression is regained in highly aggressive melanoma cell lines, invasive VGP melanoma and melanoma metastases, (202). These findings implicate Nodal as a new diagnostic marker in melanoma progression and a novel target for treatment of metastatic melanoma (195).

\section{CONCLUSIONS AND PERSPECTIVES}

A better understanding of melanoma biology has evolved over the past few years from molecular studies. Despite a wealth of data on chromosomal alterations, mutational analysis in key melanoma genes, epigenetic modifications, transcriptome profiles and interactions of melanoma cells with the microenvironment, the picture on the molecular biology of melanoma is far to be complete. Until today, tumor thickness and presence or absence of ulceration remain as the factors with best prognostic significance in primary cutaneous melanoma. In addition, melanoma is still a tumor refractory to chemotherapy treatment. Nevertheless, future advances in this area probably will improve our understanding of the heterogeneity of melanoma and will lead to a more precise taxonomy of this disease. Hopefully, the discovery of new individual signaling pathways known to be dysregulated in melanoma, such as Notch and Nodal, will favour the design and testing of novel therapeutic agents to treat advanced melanoma.

\section{ACKNOWLEDGEMENTS}

The authors apologize to the many investigators whose primary research articles could not be cited in this review because of space limitations. Work in our laboratory is funded by the Spanish Ministry of Education (grant SAF2007-63821) and the company Digna Biotech.

\section{REFERENCES}

1. Becker C.J., J.M. Kirkwood, S.S. Agarwala, R. Dummer, D. Schrama \& A. Hauschild: Molecular targeted therapy for melanoma: Current reality and future options. Cancer 107, 2317-2327 (2006)
2. Hussein M.R.: Ultraviolet radiation and skin cancer: molecular mechanisms. J Cutan Pathol 32, 191-205 (2005) 3. de Gruijl F.R. \& J.C. van der Leun: Physical variables in experimental photocarcinogenesis and quantitative relationships between stages of tumor development. Front Biosci 7, d1525 (2002)

4. Jhappan C., F.P. Noonan \& G. Merlino: Ultraviolet radiation and cutaneous malignant melanoma. Oncogene 22, 3099-3112 (2003)

5. Clark Jr. W.H., D.E. Elder \& M. van Horn: The biologic forms of malignant melanoma. Hum Pathol 17, 443-450 (1986)

6. Takata M. \& T. Saida: Genetic alterations in melanocytic tumors. J Derm Sci 43, 1-10 (2006)

7. Ackerman A.B.: Malignant melanoma: a unifying concept. Hum Pathol 11, 591-595 (1980)

8. Chudnovski Y., P.A. Khavari \& A.E. Adams: Melanoma genetics and the development of rational therapeutics. J Clin Invest 115, 813-824 (2005)

9. Clark Jr. W.H., D.E. Elder, D. Guerry IV, M.N. Epstein, M.H. Green \& M. van Horn: A study of tumor progression: the precursor lesions of superficial spreading and nodular melanoma. Hum Pathol 15, 11471165 (1984)

10. Chin L.: The genetics of malignant melanoma: lessons from mouse and man. Nat Rev Cancer 3, 559570 (2003)

11. Bishop J.N., M. Harland, J. Randerson-Moor \& D.T. Bishop: Management of familial melanoma. Lancet Oncol 8, 46-54 (2007)

12. Palmer J.S., D.L. Duffy, N.F. Box, J.F. Aitken, L.E. O'Gorman, A.C. Green, N.K. Hayward, N.G. Martin \& R.A. Sturm: Melanocortin-1 receptor polymorphisms and risk of melanoma: Is the association explained solely by pigmentation phenotype ? Am J Hum Genet 66, 176-186 (2000)

13. Healy E., S.A. Jordan, P.S. Budd, R. Suffolk, J.L. Rees \& I.J. Jackson: Functional variation of MC1R alleles from red-haired individuals. Hum Mol Genet 10, 2397$2402(2001)$

14. Valverde P., E. Healy, I. Jackson, J.L. Rees \& A.J. Thody: Variants of the melanocyte stimulating hormone receptor gene are associated with red hair and fair skin in humans. Nat Genet 11, 328-330 (1995)

15. Box N.F., D.L. Duffy, W. Chen, M. Stark, N.G. Martin, R.A. Sturm \& N.K. Hayward: MC1R genotype modifies risk of melanoma in families segregating CDKN2A mutation. Am J Hum Genet 69, 765-773 (2001)

16. van der Velden P.A., L.A. Sandkuijl, W. Bergman, S. Pavel, L. van Mourik, R.R. Frants \& N.A. Gruis: Melanocortin-1 receptor variant R151C modifies melanoma risk in Dutch families with melanoma. $\mathrm{Am} \mathrm{J}$ Hum Genet 69, 774-779 (2001)

17. Daya-Grosjean L. \& A. Sarasin: The role of UV induced lesions in skin carcinogenesis: an overview of oncogene and tumor suppressor gene modifications in xeroderma pigmentosum skin tumors. Mutat Res 571, 43$56(2005)$

18. Hussussian C.J., I.P. Struewing, A.M. Goldstein, P.A. Higgins, D.S. Ally, M.D. Sheahan, W.H. Jr. Clark, M.A. Tucker \& N.C. Dracopoli: Germline p16 mutations in familial melanoma. Nat Genet 8, 15-21 (1994) 
19. Kamb A., D. Shattuck-Eidens, R. Eeles Q. Liu, N.A. Gruis, W. Ding, C. Hussey, T. Tran, Y. Miki, J. WeaverFeldhaus, M. McClure, J.F. Aitkens, D.E. Anderson, W. Bergman, R. Frants, D.E. Goldgar, A. Green, R. MacLennan, N.G. Martin, L.J. Meyer, P. Youl, J.J. Zone, M.H. Skolnick \& L.A. Cannon-Albright: Analysis of the p16 gene (CDKN2) as a candidate for the chromosome 9p melanoma susceptibility locus. Nat Genet 8, 23-26 (1994)

20. Serrano M., G.J. Hannon \& D. Beach: A new regulatory motif in cell-cycle control causing specific inhibition of cyclin D/CDK4. Nature 366, 704-707 (1993)

21. Pomerantz J., N. Schreiber-Agus, N.J. Liegeois, A. Silverman, L. Alland, L. Chin, J. Potes, K. Chen, I. Orlow, H.W. Lee, C. Cordon-Cardo \& R.A. DePinho: The Ink4a tumor suppressor gene product, p19Arf, interacts with MDM2 and neutralizes MDM2's inhibition of p53. Cell 92, 713-723 (1998)

22. Zhang Y., Y. Xiong \& W.J. Yarbrough: ARF promotes MDM2 degradation and stabilizes p53: ARFINK4a locus deletion impairs both the $\mathrm{Rb}$ and $\mathrm{p} 53$ tumor suppression pathways. Cell 92, 725-734 (1998)

23. Kamijo T., J.D. Weber, G. Zambetti . Zindy, M.F. Roussel \& C.J. Sherr: Functional and physical interactions of the ARF tumor suppressor with p53 and Mdm2. Proc Natl Acad Sci USA 95, 8292-8297 (1998)

24. Stott F.J., S. Bates, M.C. James, B.B. McConnell, M. Starborg, S. Brookes, I. Palmero, K. Ryan, E. Hara, K.H. Vousden \& G. Peters: The alternative product from the human CDKN2A locus, p14(ARF), participates in a regulatory feedback loop with $\mathrm{p} 53$ and MDM2. EMBO J 17, 5001-5014 (1998)

25. Chin L., L.A. Garraway LA \& D.E. Fisher: Malignant melanoma: genetics and therapeutics in the genomic era. Genes Dev 20, 2149-2182 (2006)

26. Randerson-Moor J.A., M. Harland, S. Williams, D. Cuthbert-Heavens, E. Sheridan, J. Aveyard, K. Sibley, L. Whitaker, M. Knowles, J.N. Bishop \& D.T. Bishop: A germline deletion of p14(ARF) but not CDNK2A in a melanoma-neural system tumour syndrome family. Human Mol Genet 10, 55-62 (2001)

27. Rizos H., S. Puig, C. Badenas, J. Malvehy, A.P. Darmanian, L. Jimenez, M. Milà \& R.F. Kefford: A melanoma-associated germline mutation in exon 1beta inactivates p14ARF. Oncogene 20, 5543-5547 (2001)

28. Hewitt C., W.C. Lee, G. Evans, A. Howell, R.G. Elles, R. Jordan, P. Sloan, A.P. Read \& N. Thakker: Germline mutation of ARF in a melanoma kindred. Human Mol Genet 11, 1273-1279 (2002)

29. Bishop D.T., F. Demenais, A.M. Goldstein, W Bergman, J.N. Bishop, B. Bressac-de Paillerets, A. Chompret, P. Ghiorzo, N. Gruis, J. Hansson, M. Harland, N. Hayward, E.A. Holland, G.J. Mann, M. Mantelli, D. Nancarrow, A. Platz \& M.A. Tucker; Melanoma Genetics Consortium: Geographical variation in the penetrance of $C D K N 2 A$ mutations for melanoma. J Natl Cancer Inst 94, 894-903 (2002)

30. Gandini S., F. Sera, M.S. Cattaruzza, P. Pasquini, D. Abeni, P. Boyle \& C.F. Melchi: Meta-analysis of risk factors for cutaneous melanoma. I. Common and atypical naevi. Eur J Cancer 41, 28-44 (2005)
31. Bergman W., P. Watson, J. de Jong, H.T. Lynch \& R.M. Fusaro: Systemic cancer and the FAMM syndrome. Br J Cancer 61, 932-936 (1990)

32. Lynch H.T. \& R.M. Fusaro: Pancreatic cancer and the familial atypical multiple mole melanoma (FAMM) syndrome. Pancreas 6, 127-131 (1991)

33. Goldstein A. M., M. Chan, M. Harland, E.M. Gillanders, N.K. Hayward, M.F. Avril, E. Azizi, G. Bianchi-Scarra, D.T. Bishop, B. Bressac-de Paillerets, W. Bruno, D. Calista, L.A. Cannon-Albright, F. Demenais, D.E. Elder, P. Ghiorzo, N.A. Gruis, J. Hanson, D. Hogg, E.A. Holland, P.A. Kanetsky, R.F. Kefford, M.T. Landi, J. Lang, S.A. Leachman, R.M. Mackie, V. Magnusson, G.J. Mann, K. Niendorf, J. Newton Bishop, J.M. Palmer, S. Puig, J.A. Puig-Butille, F.A. Snoo, M. Stark, H. Tsao, M.A. Tucker, L. Whitaker \& E. Yakobson: High-risk melanoma susceptibility genes and pancreatic cancer, neural system tumors and uveal melanoma across genoMEL. Cancer Res 66, 9818-9828 (2006)

34. Wolfel T., M. Hauer, J. Schneider, M. Serrano, C. Wölfel, E. Klehman-Hieb, E. De Plaen, T. Hankeln, K.H.M. zum Büschenfelde \& D. Beach: A p16INK4ainsensitive CDK4 mutant targeted by cytollytic Tlymphocytes in a human melanoma. Science 269, 12811284 (1995)

35. Zuo L., J. Weger, Q. Yang, A.M. Goldstein, M.A. Tucker, G.J. Walker, N. Hayward \& N.C. Dracopoli: Germ-line mutations in the p16INK4a binding domain of CDK4 in familial melanoma. Nat Genet 12, 97-99 (1996)

36. Soufir N., M.F. Avril, A. Chompret, F. Demenais, J. Bombled, A. Spatz, D. Stoppa-Lyonnet, J. Bernard \& B. Bressac-de Paillerets: Prevalence of p16 and CDK4 germline mutations in 48 melanome-prone families in France. Human Mol Genet 7, 209-216 (1998)

37. Ruas J.R., F. Gregory, S. Moulin, D. Delia, S. Manoukian, J. Rowe, S. Brookes \& G. Peters: A CDKN2A mutation in familial melanoma that abrogates binding of p16INK4A to CDK4 but not CDK6. Cancer Res 67, 9134-9141 (2007)

38. Goldstein A.M., J.P. Struewing, A. Chidambaram, M.C. Fraser \& M.A. Tucker: Genotype-phenotype relationship in US melanoma-prone families with CDKN2A and CDK4 mutations. J Natl Cancer Inst 92, 1006-1010 (2000)

39. de Snoo FA and Hayward NK: Cutaneous melanoma susceptibility and progression genes. Cancer Lett 230, 153-186 (2005)

40. Sotillo R., J.F. Garcia, S. Ortega, J. Martin, P. Dubus, M. Barbacid \& M. Malumbres: Invasive melanoma in cdk4-targeted gene. Proc Natl Acad Sci USA 98, 13312-13317 (2001)

41. Eng C., F.P. Li, D.H. Abramson, R.M. Ellsworth, F.L. Wong, M.B. Goldman, J. Seddon, N. Tarbell \& J.D. Jr. Boice: Mortality from second tumors among long-term survivors of retinoblastoma. J Natl Cancer Inst 85, 11211128 (1993)

42. Fletcher O., D. Easton, K. Anderson, C. Gilham, M. Jay \& J. Peto: Lifetime risks of common cancer among retinoblastoma survivors. $J$ Natl Cancer Inst 96, 357-363 (2004)

43. Gillanders E., S.H. Juo, E.A. Holland, M. Jones, D. Nancarrow, D. Freas-Lutz, R. Sood, N. Park, M. Faruque, 
C. Markey, R.F. Kefford, J. Palmer, W. Bergman, D.T. Bishop, M.A. Tucker, B. Bressac-de Paillerets, J. Hansson, M. Stark, N. Gruis, J.N. Bishop, A.M. Goldstein, J.E. Bailey-Wilson, G.J. Mann, N. Hayward \& J. Trent: Localization of a novel melanoma susceptibility locus to 1p22. Am J Hum Genet 73, 30113 (2003)

44. Walker G.J., J.O. Indsto, R. Sood, M.U. Faruque, P. $\mathrm{Hu}$, P.M. Pollock, P. Duray, E.A. Holland, K. Brown, R.F. Kefford, J.M. Trent, G.J. Mann \& N.K. Hayward: Deletion mapping suggests that the 1p22 melanoma susceptibility gene is a tumor suppressor localized to a 9-Mb interval. Genes Chromosomes Cancer 41, 56-64 (2004)

45. Bertolotto C., P. Abbe, T.J. Hemesath, K. Bille, D.E. Fisher, J.P. Ortonne \& R. Balotti: Microphthalmia gene product as a signal transducer in cAMP-induced differentiation of melanocytes. J Cell Biol 142, 827-835 (1998)

46. Price E.R., M.A. Horstman, A.G. Wells, K.N. Weilbaecher, C.M. Takemoto, M.W. Landis \& D.E. Fisher: A-Melanocyte-stimulating hormone signaling regulate expression of microphtalmia, a gene deficient in Waanderburg syndrome. J Biol Chem 273, 3304233047 (1998)

47. Kadekaro A.L., H. Kanto, R. Kavanagh \& Z.A. Abdel-Malek: Significance of melanocortin 1 receptor in regulating human melanocyte pigmentation, proliferation and survival. Ann NY Acad Sci 994, 359365 (2003)

48. Gandini S., F. Sera, M.S. Cattaruzza, P. Pasquini, O. Picconi, P. Boyle \& C.F. Melchi: Meta-analysis of risk factors for cutaneous melanoma. II. Sun exposure. Eur $J$ Cancer 41, 45-60 (2005)

49. Siskind V., J. Aitken, A. Green \& N. Martin: Sun exposure and interaction with family history in risk of melanoma, Queensland, Australia. Int J Cancer 97, 9095 (2002)

50. Grafstrom E., S. Egyhazi, U. Ringborg, J. Hansson \& A. Platz: Biallelic deletions in INK4 in cutaneous melanoma are common and associated with decreased survival. Clin Cancer Res 11, 2991-2997 (2005)

51. Straume O., J. Smeds, R. Kumar, K. Hemminki \& L.A. Akslen: Significant impact of promoter hypermethylation and the $540 \mathrm{C}>\mathrm{T}$ polymorphism of CDKN2A in cutaneous melanoma of the vertical growth phase. Am J Pathol 161, 229-237 (2002)

52. van der Velden P.A., J.A. Metzelaar-Blok, W. Bergman, H. Monique, H. Hurks, R.R. Frants, N.A. Gruis \& M.J. Jager: Promoter hypermethylation is common cause of reduced p16(INK4a) expression in uveal melanoma. Cancer Res 61, 5303-5306 (2001)

53. Rastetter M., U. Shagdarsurengin, C. Lahtz, E. Fiedler, W.Ch. Marsch, R. Dammann \& P. Helmbold: Frequent intra-tumoral heterogeneity of promoter hypermethylation in malignant melanoma. Histol Histopathol 22, 1005-1015 (2007)

54. Pons M. \& M. Quintanilla: Molecular biology of malignant melanoma and other cutaneous tumors. Clin Transl Oncol 8, 466-474 (2006)

55. Miller A.J.\& M.C. Mihm Jr: Mechanisms of disease. Melanoma. New Engl J Med 355, 51-65 (2006)
56. Sherr C. J.: Divorcing Arf and p53: an unsettled case. Nat Rev Cancer 6, 663-673 (2006)

57. Ha L., T. Ichikawa, M. Anver, R. Dickins, S. Lowe, N.E. Sharpless, P. Krimpenfort, R.A. DePinho, D.C. Bennett, E.V. Sviderskaya \& G. Merlino: ARF functions as a melanoma tumor suppressor by inducing p53independent senescence. Proc Natl Acad Sci USA 104, 10968-10973 (2007)

58. Yang G., D. Curley, M.W. Bosenberg \& H. Tsao: Loss of xeroderma pigmentosum $\mathrm{C}$ (Xpc) enhances melanoma photocarcinogenesis in Ink4a-Arf-deficient mice. Cancer Res 67, 5649-5657 (2007)

59. Hsu M.Y., F. Meier \& M. Herlyn. Melanoma development and progression: a conspiracy between tumor and host. Differentiation 70, 522-536 (2002)

60. Li G., H. Schaider, K. Satyamoorthy, Y. Hanakawa, K. Hashimoto \& M. Herlyn: Downregulation of Ecadherin and desmoglein 1 by autocrine hepatocyte growth factor during melanoma development. Oncogene 20, 8125-8135 (2001)

61. Natali PG, M.R. Nicotra, M.F. Di Renzo, M. Prat, A. Bigotti, R. Cavalieri \& P.M. Comoglio: Expression of cMet/HGF receptor in human melanocytic neoplasms: Demonstration of the relationship to malignant melanoma tumor progression. Br J Cancer 68, 746-750 (1993)

62. Cruz J., J.S. Reis-Filho, P. Silva \& J.M. Lopes: Expression of c-met tyrosine kinase receptor is biologically and prognostically relevant for primary cutaneous melanomas. Oncology 65, 72-82 (2003)

63. Wiltshire R.N., P. Duray, M.L. Bittner, T. Visakorpi, P.S. Meltzer, R.J. Tuthill, L.A. Liotta \& J.M. Trent: Direct visualization of the clonal progression of primary cutaneous melanoma: Application of tissue microdissection and comparative genomic hybridization. Cancer Res 55, 3954-3957 (1995)

64. Bastian B.C., P.E. LeBoit, H. Hamm, E.B. Bröcker $\&$ D. Pinkel: Chromosomal gains and losses in primary cutaneous melanomas detected by comparative genomic hybridization. Cancer Res 58, 2170-2175 (1998)

65. Puri N., S. Ahmed, V. Janamanchi, M. Tretiakova, O. Zumba, T. Krausz, R. Jagadeeswaran \& R. Salgia: cMet is a potentially new therapeutic target for treatment of human melanoma. Clin Cancer Res 13, 2246-2253 (2007)

66. Hsu M., T. Andl, G. Li, J.L. Meinkoth \& M. Herlyn: Cadherin repertoire determines pattern-specific gap junctional communication during melanoma progression. J Cell Sci 113, 1535-1542 (2000)

67. Valyi I.T.-Nagy, G. Hirka, P.J. Jensen, I.M. Shih, I. Juhasz \& M. Herlyn: Undifferentiated keratinocytes control growth, morphology, and antigen expression of normal melanocytes through cell-cell contacts. Lab Invest 69, 152159 (1993)

68. McGill G.G., R. Haq, E.K. Nishimura \& D.E. Fisher: cMet expression is regulated by Mitf in the melanocytic lineage. J Biol Chem 281, 10365-10373 (2006)

69. Koprowski H., M. Herlyn, C. Balaban, A. Parmiter, A. Ross \& P. Nowell: Expression for the receptor for epidermal growth factor correlates with increased dosage of chromosome 7 in malignant melanoma. Somat Cell Mol Genet 11, 297-302 (1985) 
70. Blume-Jensen P. \& T. Hunter: Oncogenic kinase signalling. Nature 411, 355-365 (2001)

71. J. Sebolt-Leopold and R. Herrera: Targeting the mitogen-activated protein kinase cascade to treat cancer. Nat Rev Cancer 4, 937-947 (2004)

72. Pollock P.M., U.L. Harper, K.S. Hansen, L.M. Yudt, M. Stark, C.M. Robbins, T.Y. Moses, G. Hostetter, U. Wagner, J. Kakareka, G. Salem, T. Pohida, P. Heenan, P. Duray, O. Kullionemi, N.K. Hayward, J.M. Trent \& P.S. Meltzer: High frequency of BRAF mutations in nevi. Nat Genet 33, 19-20 (2003)

73. Uribe P, I.I. Wistuba \& S. Gonzalez: BRAF mutation: a frequent event in benign, atypical and malignant melanocytic lesions of the skin. Am J Dermatophatol 25, 365-370 (2003)

74. Maldonado J.L., J. Fridlyand, H. Patel, A.N. Jain, K. Busam, T. Kageshita, T. Ono, D.G. Albertson, D. Pinkel \& B.C. Bastian: Determinants of BRAF mutations in primary melanomas. J Natl Cancer Inst 95, 1878-1890 (2003)

75. Dhomen N. \& R. Marais: New insights into BRAF mutations in cancer. Curr Op Genet Dev 17, 31-39 (2007)

76. Ueda Y. \& A. Richmond: NF-kB activation in melanoma. Pigment Cell Res 19, 112-124 (2006)

77. Kumar R., S. Angelini, E. Snellman \& K. Hemminki: BRAF mutations are common somatic events in melanocytic nevi. J Invest Dermatol 122, 342-348 (2004)

78. Michaloglou C., L.C. Vedreveld, M.S. Soengas, C. Denoyelle, T. Kuilman, C.M. van der Horst, D.M. Majoor, J.W. Shay, W.J. Mooi \& D.S. Peeper: BRAFE600associated senescence-like cell cycle arrest of human naevi. Nature 436, 720-724 (2005)

79. Davies H., G.R. Bignell, C. Cox, P. Stephens, S. Edkins, S. Clegg, J. Teague, H. Woffendin, M.J. Garnett, W. Bottomley, N. Davis, E. Dicks, R. Ewing, Y. Floyd, K. Gray, S. Hall, R. Hawes, J. Huges, V. Kosmidou, A. Menzies, C. Mould, A. Parker, C. Stevens, S. Watt, S. Hooper, R. Wilson, H. Jayatilake, B.A. Gusterson, C. Cooper, J. Shipley, D. Hargrave, K. Pritchard-Jones, N. Maitland, G. Chevenix-Trench, G.J. Riggins, D.D. Bigner, G. Palmieri, A. Cossu, A. Flanagan, A. Nicholson, J.W. Ho, S.Y. Leung, S.T. Yuen, B.L. Weber, H.F. Seigler, T.L. Darrow, H. Paterson, R. Marais, C.J. Marshall, R. Wooster, M.R. Stratton \& P.A. Fruteal: Mutations of the BRAF gene in human cancer. Nature 417, 949-954 (2002)

80. Curtin J.A., J. Fridlyan, T. Kageshita, H.N. Patel, K.J. Busam, H. Kutzner, K.H. Cho, S. Aiba, E.B. Bröcker, P.E. LeBoit, D. Pinkel \& B.C. Bastian: Distinct sets of genetic alterations in melanoma. $N$ Engl J Med 353, 2135-2147 (2005)

81. Libra M., G. Malaponte, V. Bevelacqua, R. Siciliano, P. Castrogiovanni, A. Fulvi, G. Micali, G. Ligresti, M.C. Mazzarino, F. Stivala, S. Travali \& J.A. McCubrey: Absence of BRAF gene mutation in non-melanoma skin tumors. Cell Cycle 5, 968-970 (2006)

82. Demunter A., M. Stas, H. Degreef, C. de Wolf-Peeters \& J.J. van den Oord: Analysis of N- and K-ras mutations in the distinctive tumor progression phases of melanoma. $J$ Invest Dermatol 117, 1483-1489 (2001)

83. Papp T., H. Pemsel, R. Zimmermann, R. Bastrop, D.G. Weiss \& D. Schiffmann: Mutational analysis of the N.ras, p53, p16INK4a, CD4 and MC1R genes in human congenital melanocytic naevi. J Med Genet 36, 610-614 (1999)

84. M. Jafari, T. Papp, S. Kirchner, U. Diener, D. Henschler, G. Burg and D. Schiffmann: Analysis of ras mutations in human melanocytic lesions: activation of the ras gene seems to be associated with the nodular type of human malignant melanoma. J Cancer Res Clin Oncol 121, 23-30 (1995)

85. van Elsas A., S.F. Zerp, S. van der Flier, F.M. Krüse, C. Aarnoudse, N.K. Hayward, D.J. Ruiter \& P.I. Schrier: Relevance of ultraviolet-induced N-ras oncogene point mutations in development of primary human cutaneous melanoma. Am J Pathol 149, 883-893 (1996)

86. Solit D.B., L.A. Garraway, C.A. Pratilas, A. Sawai, G. Getz, A. Basso, Q. Ye, J.M. Lobo, Y. She, I. Osman, T.G. Golub, J. Sebolt-Leopard, W.R. Sellers \& N. Rosen: BRAF mutations predict sensitivity to MEK inhibition. Nature 439, 358-362 (2006)

87. Vivanco I. \& C.L. Sawyers: The phosphatidylinositol 3kinase-AKT pathway in human cancer. Nat Rev Cancer 2, 499-501 (2002)

88. Myers M.P., I. Pass, I.H. Batty, J. Van der Kaay, J.P. Stolarov, B.A. Hemmings, M.H. Wigler, C.P. Downes \& N.K. Tonks: The lipid phosphatase activity of PTEN is critical for its tumor supressor function. Proc Natl Acad Sci USA 95, 13513-13518 (1998)

89. Isshiki K., D. Guerry, D.E. Elder \& A.J. Linnenbach: Chromosome 10 allelic loss in malignant melanoma. Genes Chromosomes Cancer 8, 178-184 (1993)

90. Guldberg P., P. thor Straten, A. Birck, V. Ahrenkiel, A.F. Kirkin, \& J. Zeuthen: Disruption of the MMAC1/PTEN gene by deletion or mutation is a frequent event in malignant melanoma. Cancer Res 57, 3660-3663 (1997)

91. Tsao H., X. Zhang, E. Benoit \& F.G. Haluska: Identification of PTEN/MMAC1 alterations in uncultured melanomas and melanoma cell lines. Oncogene 16, 33973402 (1998)

92. Tsao H., V. Goel, H. Wu, G. Yang \& F.G. Haluska: Genetic interaction between NRAS and BRAF mutations and PTEN/MMAC1 inactivating mutation in melanoma. $J$ Invest Dermatol 122, 337-341 (2004)

93. Mirmohammadsadegh A., A. Marini, S. Nambiar, M. Hassan, A. Tannapfel, T. Ruzicka \& U.R. Hengge: Epigenetic silencing of the PTEN gene in melanoma. Cancer Res 66, 6546-6552 (2006)

94. Sthal J. M., A. Sharma, M. Cheung, M. Zimmerman, J.Q. Cheng, M.W. Bosenberg, M. Kester, L. Sandirasegarane \& G.P. Robertson: Deregulated Akt3 activity promotes development of malignant melanoma. Cancer Res 64, 7002-7010 (2004)

95. Slipicevic A., R. Holm, M.T. Nguyen, P.J. Bøhler, B. Davidson \& V.A. Flørenes: Expression of activated Akt and PTEN in malignant melanomas: Relationship with clinical outcome. Am J Clin Pathol 124, 528-536 (2005)

96. Levy C., M. Khaled \& D.E. Fisher: MITF: master regulator of melanocyte development and melanoma oncogene. Trends Mol Med 12, 406-414 (2006)

97. Steingrimsson E., N.G. Copeland \& N.A. Jenkins: Melanocytes and the microphthalmia transcription factor network. Annu Rev Genet 38, 365-411 (2004) 
98. Tassabehji M., V.E. Newton \& A.P. Read: Waardenburg syndrome type 2 caused by mutations in the human microphthalmia (MITF) gene. Nat Genet 8, 251-255 (1994)

99. Hershey C.L. \& D.E. Fisher: Genomic analysis of the Microphthalmia locus and identification of the MITF-J/Mitf-J isoform. Gene 347, 73-82 (2005)

100. Fuse N., K. Yasumoto, H. Suzuki, K. Takahashi \& S. Shibahara: Identification of a melanocyte-type promoter of the microphtalmia-associated transcription factor gene. Biochem Biophys Res Commun 219, $702-$ 707 (1996)

101. Huber W.E., E.R. Price, H.R. Widlund, J. Du, I.J. Davis, M. Wegner \& D.E. Fisher: A tissue-restricted cAMP transcriptional response: SOX10 modulates alpha-melanocyte-stimulating hormone-triggered expression of microphthalmia-associated transcription factor in melanocytes. $J$ Biol Chem 278, 45224-45230 (2003)

102. Dorski R.I., D.W. Daible \& R.T. Moon: Direct regulation of nacre, a zebrafish MITF homolog required for pigment cell formation, by the Wnt pathway. Genes Dev 14, 158-162 (2000)

103. Takeda K., K. Yasumoto, R. Takada, S. Takada, K. Watanabe, T. Udono, H. Saito, K. Takahashi \& S. Shibahara: Induction of melanocyte-specific microphtalmia-associated transcription factor by Wnt3a. J Biol Chem 275, 14013-14016 (2000)

104. Widlund H.R., M.A. Horstmann, E.R. Price, J. Cui, S.L. Lessnick, M. Wu, X. He \& D.E. Fisher: Betacatenin-induced melanoma growth requieres the downstream target Microphtalmia-associated transcription factor. J Cell Biol 158, 1079-1087 (2002)

105. Wu M., T.J. Hemesath, C.M. Takemoto, M.A. Horstmann, A.G. Wells, E.R. Price, D.Z. Fisher \& D.E. Fisher: c-Kit triggers dual phosphorylations, which couple activation and degradation of the essential melanocyte factor Mi. Genes Dev 14, 301-312 (2000)

106. Price E.R., H.F. Ding, T. Badalian, S. Bhattacharya, C. Takemoto, T.P. Yao, T.J. Hemesath \& D.E. Fisher: Lineage-specific signaling in melanocytes. C-kit stimulation recruits p300/CBP to microphthalmia. $J$ Biol Chem 273, 17983-17986 (1998)

107. Garraway L.A., H.R. Widlund, M.A. Rubin, G. Getz, A.J. Berger, S. Ramaswamy, R. Beroukhim, D.A. Milner, S.R. Granter, J. Du, C. Lee, S.N. Wagner, C. Li, T.R. Golub, D.L. Rimm, M.L. Meyerson, D.E. Fisher \& W.R. Sellers: Integrative genomic analyses identify MITF as a lineage survival oncogene amplified in malignant melanoma. Nature 436, 117-122 (2005)

108. Ugurel S., R. Houben, D. Schrama, H. Voigt, M. Zapatka, D. Schadendorf, E.B. Bröcker \& J.C. Becker: Microphthalmia-associated transcription factor gene amplification in metastatic melanoma is a prognostic marker for patient survival, but not a predictive marker for chemosensitivity and chemotherapy response. Clin Cancer Res 3, 6344-6350 (2007)

109. Salti G.I., T. Manougian, M. Farolan, A. Shilkaitis, D. Majumdar \& T.K. Das Gupta: Microphthalmia transcription factor: a new prognostic marker in intermediate-thickness cutaneous malignant melanoma. Cancer Res 60, 5012-5016 (2000)
110. Wellbrock C. \& R. Marais: Elevated expression of MITF counteracts B-RAF-stimulated melanocyte and melanoma cell proliferation. J Cell Biol 170, 703-708 (2005)

111. Cavallaro U. \& G. Christofori: Cell adhesion and signalling by cadherins and Ig-CAMS in cancer. Nat Rev Cancer 4, 121-132 (2004)

112. Moon R.T., A.D. Kohn, G.V. de Ferrari \& A. Kaykas: WNT and -catenin signalling: diseases and therapies. Nat Rev Genet 5, 689-699 (2004)

113. Dorsky R.I., R.T. Moon \& D.V. Raible: Control of neural crest cell fate by the Wnt signalling pathway. Nature 396, 370-373 (1998)

114. Rimm D.L., K. Caca, G. Hu, F.B. Harrison \& E.R. Fearon: Frequent nuclear/cytoplasmic localization of catenin without exon 3 mutations in malignant melanoma. Am J Pathol 154, 325-329 (1999)

115. Larue L. \& V. Delmas: The Wnt/beta-catenin pathway in melanoma. Front Biosci 11, 733-742 (2006) 116. Rubinfeld B., P. Robbins, M. El-Gamil, I. Albert, E. Porfiri \& P. Polakis: Stabilization of beta-catenin by genetic defects in melanoma cell lines. Science 275, 1790-1792 (1997)

117. Demunter A., L. Libbrecht, H. Degreef, C. De Wolf-Peeters \& J.J. van den Oord: Loss of membranous expression of beta-catenin is associated with tumor progression in cutaneous melanoma and rarely caused by exon 3 mutations. Mod Pathol 15, 454-461 (2002)

118. Reifenberger J.C.B., C.B. Knobbe, M. Wolter, B. Blaschke, K.W. Schulte, T. Pietsch, T. Ruzicka \& G. Reifenberger: Molecular genetic analysis of malignant melanomas for aberrations of the WNT signalling pathway genes CTNNB1, APC, ICAT and BTRC. Int $J$ Cancer 100, 549-556 (2002)

119. Larue L. \& F. Beermann: Cutaneous melanoma in genetically modified animals. Pigment Cell Res 20, 485497 (2007)

120. Bradl M., A. Klein-Szanto, S. Porter \& B. Mintz: Malignant melanoma in transgenic mice. Proc Natl Acad Sci USA 88, 164-168 (1991)

121. Kelsall S.R. \& B. Mintz: Metastatic cutanoeus melanoma promoted by ultraviolet radiation in mice with transgeneinitiated low melanoma susceptibility. Cancer Res 58, 40614065 (1998)

122. Klein-Szanto A.J., W.K. Silvers \& B. Mintz: Ultraviolet radiation-induced malignant skin melanoma in melanomasusceptible transgenic mice. Cancer Res 54, 4569-4572 (1994) 123. Sharpless N.E., N. Bardeesy, K.H. Lee, D. Carrasco, D.H. Castrillon, A.J. Aguirre, E.A. Wu, J.W. Horner \& R.A. DePinho: Loss of p16Ink4a with retention of p19Arf predisposes mice to tumorigenesis. Nature 413, 86-91 (2001) 124. Krimpenfort P., K.C. Quon, W.J Mooi, A. Loonstra \& A. Berns: Loss of p16Ink4a confers susceptibility to metastatic melanoma in mice. Nature 413, 83-86 (2001)

125. You M.J., D.H. Castrillon, B.C. Bastian, R.C. O'Hagan, M.W. Bosenberg, R. Parsons, L. Chin \& R.A. DePinho: Genetic analysis of Pten and Ink4a/Arf interactions in the suppression of tumorigenesis in mice. Proc Natl Acad Sci USA 99, 1455-1460 (2002)

126. Rane S.G., S.C. Cosenza, R.V. Mettus \& E.P. Reddy: Germ line transmission of the Cdk4(R24C) 
mutation facilitates tumorigenesis and escape from cellular senescence. Mol Cell Biol 22, 644-656 (2002)

127. Broome-Powell M., P.R. Gause, P. Hyman, J. Gregus, M. Lluria-Prevatt, R. Nagle \& G.T. Bowden: Induction of melanoma in TPras transgenic mice. Carcinogenesis 20, 1747-1753 (1999)

128. Bardeesy N., B.C. Bastian, A. Hezel, D. Pinkel, R.A. DePinho \& Chin L: Dual inactivation of RB and p53 pathways in RAS-induced melanomas. Mol Cell Biol 21, 2144-2153 (2001)

129. Sharpless N.E., K. Kannan, J. Xu, M.W. Bosenberg \& L. Chin: Both products of the mouse Ink4a/Arf locus suppress melanoma formation in vivo. Oncogene 22, 5055-5059 (2003)

130. Kannan K., N.E. Sharpless, J. Xu, R.C. O'Hagan, M. Bosenberg \& L. Chin: Components of the $\mathrm{Rb}$ pathway are critical targets of UV mutagenesis in a murine melanoma model. Proc Natl Acad Sci USA 100, 1221-1225 (2003)

131. Chin L., A. Tam, J. Pomerantz, M. Wong, J. Holash, N. Bardeesy, Q. Shen, R. O'Hagan, J. Pantginis, H. Zhou, J.W. Horner 2nd, C. Cordon-Cardo, G.D. Yancopoulos \& R.A. DePinho: Essential role for oncogenic Ras in tumour maintenance. Nature 400, 468472 (1999)

132. Ackermann J., M. Frutschi, K. Kaloulis, T. McKee, A. Trumpp \& F. Beermann: Metastasizing melanoma formation caused by expression of activated $\mathrm{N}$ RasQ61K on an INK4a-deficient background. Cancer Res 65, 4005-4011 (2005)

133. Otsuka T., H. Takayama, R. Sharp, G. Celli, W.J. LaRochelle, D.P. Bottaro, N. Ellmore, W. Vieira, J.W. Owens, M. Anver \& G. Merlino: c-Met autocrine activation induces development of malignant melanoma and acquisition of the metastatic phenotype. Cancer Res 58, 5157-5167 (1998)

134. Takayama H., W.J. LaRochelle, R. Sharp, T. Otsuka, P. Kriebel, M. Anver, S.A. Aaronson \& G. Merlino: Diverse tumorigenesis associated with aberrant development in mice overexpressing hepatocyte growth factor/scatter factor. Proc Natl Acad Sci USA 94, 701706 (1997)

135. Noonan F.P., T. Otsuka, S. Bang, M.R. Anver \& G. Merlino: Accelerated ultraviolet radiation-induced carcinogenesis in hepatocyte growth factor/scatter factor transgenic mice. Cancer Res 60, 3738-3743 (2000)

136. Noonan F.P., J.A. Recio, H. Takayama, P. Duray, M.R. Anver, W.L. Rush, E.C. De Fabo \& G. Merlino: Neonatal sunburn and melanoma in mice. Nature 413, 271-272 (2001)

137. De Fabo E.C., F.P. Noonan, T. Fears \& G. Merlino: Ultraviolet B but not ultraviolet A radiation initiates melanoma. Cancer Res 64, 6372-6376 (2004)

138. Recio J.A., F.P. Noonan, H. Takayama, M.R. Anver, P. Duray, W.L. Rush, G. Lindner, E.C. De Fabo, R.A. DePinho \& G. Merlino: Ink4a/arf deficiency promotes ultraviolet radiation-induced melanomagenesis. Cancer Res 62, 6724-6730 (2002)

139. Patton E.E., H.R. Widlund, J.L. Kutok, K.R. Kopani, J.F. Amatruda, R.D. Murphey, S. Berghmans, E.A. Mayhall, D. Traver, C.D. Fletcher, J.C. Aster, S.R. Granter, A.T. Look, C. Lee, D.E. Fisher \& L.I. Zon: BRAF mutations are sufficient to promote nevi formation and cooperate with p53 in the genesis of melanoma. Curr Biol $15,249-254$ (2005)

140. Bardeesy N., K.K. Wong, R.A. DePinho \& L. Chin: Animal models of melanoma: recent advances and future prospects. Adv Cancer Res 79, 123-156 (2000)

141. Meierjohann S. \& M. Schartl: From Mendelian to molecular genetics: the Xiphophorus melanoma model. Trends Genet 22, 654-661 (2006)

142. Carr K.M., M. Bittner \& J.M. Trent: Gene-expression profiling in human cutaeous melanoma. Oncogene 22, 3076-3080 (2003)

143. Carlson J.A., J.S. Ross, A. Slominski, G. Linette, J. Mysliborski, J. Hill \& M. Mihm: Molecular diagnostics in melanoma. J Am Acad Dermatol 52, 743-775 (2005)

144. Kabbarah O. \& L. Chin: Revealing the genomic heterogeneity of melanoma. Cancer Cell 8, 439-441 (2005) 145. Bosserhoff A.K.: Novel biomarkers in malignant melanoma. Clin Chim Acta 367, 28-35 (2006)

146. Fecher L.A., S.D. Cummings, M.J. Keefe \& R.M. Alani: Toward a molecular classification of melanoma. $J$ Clin Oncol 25, 1606-1620 (2007)

147. Clark E.A., T.R. Golub, E.S. Lander \& R.O. Hynes: Genomic analysis of metastasis reveals an essential role for RhoC. Nature 406, 532-535 (2000)

148. de Wit N.J., H.J. Burtscher, U.H. Weidle, D.J. Ruiter \& G.N. van Muijen: Differentially expressed genes identified in human melanoma cell lines with different metastatic behaviour using high density oligonucleotide arrays. Melanoma Res 12, 57-69 (2002)

149. Baldi A., D. Santini, A. de Luca \& M.G. Paggi: cDNA array technology in melanoma: an overview. J Cell Physiol 196, 219-223 (2003)

150. Haqq C., M. Nosrati, , D. Sudilovsky, J. Crothers, D. Khodabakhsh, B.L. Pulliam, S. Federman, J.R. Miller 3rd, R.E. Allen, M.I. Singer, S.P. Leong, B.M. Ljung, R.W. Sagebiel \& M. Kashani-Sabet: The gene expression signature of melanoma progression. Proc Natl Acad Sci USA 102, 6092-6097 (2005)

151. Bittner M., P. Meltzer, Y. Chen, Y. Jiang, E. Seftor, M. Hendrix, M. Radmacher, R. Simon, Z. Yakhini, A. BenDor, N. Sampas, E. Dougherty, E. Wang, F. Marincola, C. Gooden, J. Lueders, A. Glatfelter, P. Pollock, J. Carpten, E. Gillanders, D. Leja, K. Dietrich, C. Beaudry, M. Berens, D. Alberts \& V. Sondak: Molecular classification of cutaneous malignant melanoma by gene expression profiling. Nature 406, 536-540 (2000)

152. Seftor E.A., P.S. Meltzer, D.A. Kirschmann, J. Pe'er, A.J. Maniotis, J.M. Trent, R. Folberg \& M.J.C. Hendrix: Molecular determinants of human uveal melanoma invasion and metastasis. Clin Exp Metastasis 19, 233-246 (2002)

153. Winnepenninckx V., V. Lazar, S. Michiels, P. Dessen, M. Stas, S.R. Alonso, M.F. Avril, P.L. Ortiz Romero, T. Robert, O. Balacescu, A.M. Eggermont, G. Lenoir, A. Sarasin, T. Tursz, J.J. van den Oord \& A. Spatz, Melanoma Group of the European Organization for Research and Treatment of Cancer: Gene expression profiling of primary cutaneous melanoma and clinical outcome. J Natl Cancer Inst 98, 472-483 (2006)

154. Alonso S.R., L. Tracy, P. Ortiz , B. Pérez-Gómez, J. Palacios, M. Pollán, J. Linares, S. Serrano, A.I. Sáez- 
Castillo, L. Sánchez, R. Pajares, A. Sánchez-Aguilera, M.J. Artiga, M.A. Piris \& J.L. Rodríguez-Peralto: A highthroughput study in melanoma identifies epithelialmesenchymal transition as a major determinant of metastasis. Cancer Res 67, 3450-3460 (2007)

155. Jaeger J., D. Koczan, H-J. Thiesen, S.M. Ibrahim, G. Gross, R. Spang \& M. Kunz: gene expression signatures for tumor progression, tumor subtype, and tumor thickness in laser-microdissected melanoma tissues. Clin Cancer Res $13,806-815$ (2007)

156. Lee C., B. Hong, J.M. Choi, Y. Kim, S. Watanabe, Y. Ishimi, T. Enomoto, S. Tada, Y. Kim \& Y. Cho: Structural basis for inhibition of the replication licensing factor Cdt1 by geminin. Nature 430, 913-917 (2004)

157. Becker B., A. Roesch, C. Hafner, W. Stolz, M. Dugas \& M. Landthaler: Discrimination of melanocytic tumors by cDNA array hybridization of tissues prepared by laser pressure catapulting. $J$ Invest Dermatol 122, 361-368 (2004)

158. Roesch A., B. Becker, S. Bentink, R. Spang, A. Vogl, I. Hagen, M. Landthaler \& T. Vogt: Ataxia telangiectasiamutated gene is a possible biomarker for discrimination of infiltrative deep penetrating nevi and metastatic vertical growth phase melanoma. Cancer Epidemiol Biomarkers Prev 16, 2486-2490 (2007)

159. Lavin M.F. \& S. Kozlov: ATM activation and DNA damage response. Cell Cycle 6, 931-942 (2007)

160. Jensen E.H., J.M. Lewis, J.M. McLoughlin, M.D. Alvarado, A. Daud, J. Messina, S. Enkemann, T.J. Yeatman, V.K. Sondak \& A.I. Riker: Down-regulation of pro-apoptotic genes is an early event in the progression of malignant melanoma. Ann Surg Oncol 14, 1416-1423 (2007)

161. Thiery J.P.: Epithelial-mesenchymal transitions in tumour progression. Nat Rev Cancer 2, 442-454 (2002)

162. Hoek K., D.L. Rimm, K.L. Williams, H. Zhao, S. Ariyan, A. Lin, H.M. Kluger, A.J. Berger, E. Cheng, E.S. Trombetta, T. Wu, M. Niinobe, K. Yoshikawa, G.E. Hannigan \& R. Halaban: Expression profiling reveals novel pathways in the transformation of melanocytes to melanoma. Cancer Res 64, 5270-5282 (2004)

163. Hsu M.Y., F.E. Meier, M. Nesbit, J.Y. Hsu, P. Van Belle, D.E. Elder \& M. Herlyn: E-cadherin expression in melanoma cells restore keratinocyte-mediated growth control and down-regulates expression of invasion-related adhesion receptors. Am J Pathol 156, 1515-1525 (2000)

164. Attis M.G., J.L. Burchette, M.A. Selim, T. Pham \& A.P. Soler: Differential expression of N-cadherin distinguishes a subset of metastasizing desmoplastic melanomas. Hum Pathol 37, 899-905 (2006)

165. Krengel S., F. Grotelüschen, S. Bartsch \& M. Tronnier: Cadherin expression pattern in melanocytic tumors more likely depends on the melanocytic environment than on tumor cell progression. J Cutan Pathol 31, 1-7 (2004)

166. Li G., K. Satyamoorthy \& M. Herlyn: N-cadherinmediated intercellular interactions promote survival and migration of melanoma cells. Cancer Res 61, 3819-3825 (2001)

167. Hendrix M.J., E.A. Seftor, P.S. Meltzer, L.M. Gardner, A.R. Hess, D.A. Kirschmann, G.C. Schatteman \& R.E. Seftor: Expression and functional significance of VE- cadherin in aggressive human melanoma cells: role in vasculogenic mimicry. Proc Natl Acad Sci USA 98, 80188023 (2001)

168. Hess A.R., E.A. Seftor, L.M. Gardner, K. CarlesKinch, G.B. Schneider, R.E. Seftor, M.S. Kinch \& M.J. Hendrix: Molecular regulation of tumor cell vasculogenic mimicry by tyrosine phosphorylation: role of epithelial cell kinase (Eck/EphA2). Cancer Res 61, 3250-3255 (2001)

169. Seftor R.E., E.A. Seftor, N. Koshikawa, P.S. Meltzer, L.M. Gardner, M. Bilban, W.G. Stetler-Stevenson, V. Quaranta \& M.J. Hendrix: Cooperative interactions of laminin 5 gamma2 chain, matrix metalloproteinase-2, and membrane type-1-matrix/metalloproteinase are required for mimicry of embryonic vasculogenesis by aggressive melanoma. Cancer Res 61, 6322-6327 (2001)

170. Hendrix M.J.C., E.A. Seftor, A.R. Hess \& R.E.B. Seftor: Molecular plasticity of human melanoma cells. Oncogene 32, 3070-3075 (2003)

171. Weeraratna A.T., Y. Jiang, G. Hostetter, K. Rosenblatt, P. Duray, M. Bittner \& J.M. Trent: Wnt5a signaling directly affects cell motility and invasion of metastatic melanoma Cancer Cell 1, 279-288 (2002)

172. Nambiar S., A. Mirmohammadsadegh, R. Doroudi, A. Gustrau, A. Marini, G. Roeder, T. Ruzicka \& U.R. Hengge: Signaling networks in cutaneous melanoma metastasis identified by complementary DNA microarrays. Arch Dermatol 141, 165-173 (2005)

173. Jönsson G., C. Dalh, J. Staaf, T. Sandberg, P-O. Bendahl, M. Ringnér, P. Guldberg \& A. Borg: Genomic profiling of malignant melanoma using tiling-resolution array CGH. Oncogene 26, 4738-4748 (2007)

174. Balázs M., Z. Ádám, A. Treszt, Á. Bégány, J. Hunyadi \& R. Ádány: Chromosomal imbalances in primary and metastatic melanomas revealed by comparative genomic hybridization. Cytometry 46, 222$232(2001)$

175. Speicher M.R., G. Prescher, S. du Manoir, A. Jauch, B. Horsthemke, N. Borrnfeld, R. Becher \& T. Cremer: Chromosomal gains and losses in uveal melanomas detected by comparative genomic hybridization. Cancer Res 54, 3817-3823 (1994)

176. Vajdic C.M., A.M. Hutchins, A. Kricker, J.F: Aitken, B.K. Armstrong, N.K. Hayward \& J.E. Armes: Chromosomal gains and losses in ocular melanoma detected by comparative genomic hybridization in an Australian population-based study. Cancer Genet Cytogenet 144, 12-17 (2003)

177. Bastian B.C., U. Wesselmann, D. Pinkel \& P.E. Leboit: Molecular cytogenetic analysis of Spitz nevi shows clear differences to melanoma. J Invest Dermatol 113, 1065-1069 (1999)

178. Bauer J. \& B.C. Bastian: Distinguishing melanocytic nevi from melanoma by DNA copy number changes: comparative genomic hybridization as a research and diagnostic tool. Dermatol Ther 19, 40-49 (2006)

179. White J.S., I.W. McLean, R.L. Becker, A.E. DirectorMyska \& J. Nath: Correlation of comparative genomic hybridization results of 100 archival uveal melanomas with patient survival. Cancer Genet Cytogenet 170, 29-39 (2006)

180. Häusler T., A. Stang, G. Anastassiou, K-H. Jöckel, S. Mrzyk, B. Hosthemke, D.R. Lohmann \& M. Zeschnigk: 
Loss of heterozygosity of $1 \mathrm{p}$ in uveal melanomas with monosomy 3. Int J Cancer 116, 909-913 (2005)

181. Braun K.M. \& F.M. Watt. Epidermal label-retaining cells: background and recent applications. $J$ Invest Dermatol Symp Proc 9, 196-201 (2004)

182. Dupin E. \& N.M. Le Dourain: Development of melanocyte precursors from the vertebrate neural crest. Oncogene 22, 3016-3023 (2003)

183. Yoshida H., T. Kunisada , T. Grimm, E.K. Nishimura, E. Nishioka \& S.I. Nishikawa: Review: melanocyte migration and survival controlled by SCF/c-kit expression. J Invest Dermatol Symp Proc 6, 1-5 (2001)

184. Yanagisawa M., H. Kurihara, S. Kimura, Y. Tomobe, M. Kobayashi, Y. Mitsui, Y. Yazaki, K. Goto \& T. Masaki: A novel potent vasoconstrictor peptide produced by vascular endothelial cells. Nature 332, 411-415 (1988)

185. Hemesath T.J., E.R. Price, C. Takemoto, T. Badalian \& D.E. Fisher: MAP kinase links the transcription factor microphthalmia to c-Kit signalling in melanocytes. Nature 391, 298-301 (1998)

186. Fang D., K. Leishear, T.K. Nguyen, R. Finko, K. Cai, M. Fukunaga, L. Li, P.A. Bradford, A.N. Kulp, X. Xu, K.S. Smalley \& M. Herlyn: Defining the conditions for the generation of melanocytes from human embryonic stem cells. Stem Cells 24, 1668-1677 (2006)

187. Nishimura E.K., S.A. Jordan, H. Oshima, H. Yoshida, M. Osawa, M. Moriyama, I.J. Jackson, Y. Barrandon, Y. Miyachi \& S. Nishikawa: Dominant role of the niche in melanocyte stem-cell fate determination. Nature 416, 854860 (2002)

188. Yu H., D. Fang, S.M. Kumar, L. Li, T.K. Nguyen, G. Acs, M. Herlyn \& X. Xu: Isolation of a novel population of multipotent adult stem cells from human hair follicles. $\mathrm{Am}$ J Pathol 168, 1879-1888 (2006)

189. Moriyama M., M. Osawa, S.S. Mak, T. Ohtsuka, N. Yamamoto, H. Han, V. Delmas, R. Kageyama, F. Beermann, L. Larue \& S. Nishikawa: Notch signalling via Hes1 transcription factor maintains survival of melanoblasts and melanocyte stem cells. J Cell Biol 173, 333-339 (2006)

190. Pinnix C.C.\& M. Herlyn: The many faces of Notch signalling in skin-derived cells. Pigment Cell Res 20, 458465 (2007)

191. Bray S.J.: Notch signalling: a simple pathway become complex. Nat Rev Mol Cell Biol 7, 678-689 (2006)

192. Balint K., M. Xiao, C.C. Pinnix, A. Soma, I. Veres, I. Juhasz, E.J. Brown, A.J. Capobianco, M. Herlyn \& Z.J. Liu: Activation of Notch1 signalling is required for betacatenin-mediated human primary melanoma progression. $J$ Clin Invest 115, 3166-3176 (2005)

193. Qin J.Z., L. Stennett, P. Bacon, B. Bodner, M.J. Hendrix, R.E. Seftor, E.A. Seftor, N.V. Margaryan, P.M. Pollock, A. Curtis, J.M. Trent, F. Bennett, L. Miele \& B.J. Nickoloff: p53-independent NOXA induction overcomes apoptotic resistance of malignant melanomas. Mol Cancer Ther 3, 895-902 (2004)

194. Burkert J., N.A. Wright \& M.R. Alison: Stem cells and cancer: an intimate relationship. J Pathol 209, 287-297 (2006)

195. Hendrix M.J.C., E.A. Seftor, R.E.B. Seftor, J. Kasemier-Kulesa, P.M. Kulesa \& L.M. Postovit:
Reprogramming metastatic tumour cells with embryonic microenvironments. Nat Rev Cancer 7, 246-255 (2007)

196. Fang D., T.K. Nguyen, K. Leishear, R. Finko, A.N. Kulp, S: Hotz, P.A. Van Belle, X. Xu, D.E. Elder \& M. Herlyn: Tumorigenic subpopulation with stem cell properties in melanomas. Cancer Res 65, 9328-9337 (2005) 197. Coiffier B., E. Lepage, J. Briere, R. Herbrecht, H. Tilly, R. Bouabdallah, P. Morel, E. Van Den Neste, G. Salles, P. Gaulard, F. Reyes, P. Lederlin \& C. Gisselbrecht: CHOP chemotherapy plus rituximab compared with CHOP alone in elderly patients with diffuse large-B-cell lymphoma. N Eng J Med 346, 235-242 (2002)

198. Frank N.Y., A. Margaryan, Y. Huang, T. Schatton, A.M. Waaga Gasser, M. Gasser, M.H. Sayegh, W. Sadee \& M.H. Frank: ABCB5-mediated doxorubicin transport and chemoresistance in human malignant melanoma. Cancer Res 65, 4320-4333 (2005)

199. Lee J.T. \& M. Herlyn: Microenvironmental influences in melanoma progression. $J$ Cell Biochem 101, 862-872 (2007)

200. Paget S.: The distribution of secondary growths in cancer of the breast. Cancer Metastasis Rev 8, 98-101 (1989)

201. Fidler I.J.: The pathogenesis of cancer metastasis: the "seed and soil" hypothesis revisited. Nat Rev Cancer 3, 453-458 (2003)

202. Topczewska J.M., L.M. Postovit, N.V. Margaryan, A. Sam, A.R. Hess, W.W. Wheaton, B.J. Nickoloff, J. Topczewski \& M.J. Hendrix: Embryonic and tumorigenic pathways converge via Nodal signalling: role in melanoma aggressiveness. Nat Med 12, 925-932 (2006)

Key Words: Melanoma, Susceptibility genes, Activated signaling pathways, Mouse models, Wide genomic analyses, Gene expression profiles, Stem cells, Review

Send correspondence to: Dr Miguel Quintanilla, Instituto de Investigaciones Biomedicas "Alberto Sols", Arturo Duperier 4, 28029 Madrid, Spain, Tel: 3491 5854412, Fax: 34915854401 , E-mail: mquintanilla@iib.uam.es 